\title{
Contact metamorphism in the Malashan dome, North Himalayan gneiss domes, southern Tibet: an example of shallow extensional tectonics in the Tethys Himalaya
}

\author{
T. KAWAKAMI, ${ }^{1}$ M. AOYA, ${ }^{2}$ S. R. WALLIS, ${ }^{3}$ J. LEE, ${ }^{4}$ K. TERADA, ${ }^{5}$ Y. WANG ${ }^{6}$ AND M. HEIZLER \\ ${ }^{1}$ Department of Geology and Mineralogy, Graduate School of Science, Kyoto University, Kyoto 606-8502, Japan \\ (t-kawakami@kueps.kyoto-u.ac.jp) \\ ${ }^{2}$ Institute of Geology and Geoinformation, National Institute of Advanced Industrial Science and Technology, Central 7, \\ Tsukuba, Ibaraki 305-8567, Japan \\ ${ }^{3}$ Department of Earth and Planetary Sciences, Graduate School of Environmental Studies, Nagoya University, Nagoya \\ 464-8602, Japan \\ ${ }^{4}$ Department of Geological Sciences, Central Washington University, Ellensburg, WA 98926, USA \\ ${ }^{5}$ Department of Earth and Planetary Systems Science, Graduate School of Science, Hiroshima University, \\ Hiroshima 739-8526, Japan \\ ${ }^{6}$ Department of Geology, China University of Geosciences, Beijing 100083, China \\ ${ }^{7}$ New Mexico Bureau of Mines \& Mineral Resources, New Mexico Tech, 801 Leroy Place, Socorro NM 87801-4796, USA
}

\begin{abstract}
Combined petrographic, structural and geochronological study of the Malashan dome, one of the North Himalayan gneiss domes, reveals that it is cored by a Miocene granite, the Malashan granite, that intruded into the Jurassic sedimentary rocks of Tethys Himalaya. Two other granites in the area are referred to as the Paiku and Cuobu granites. New zircon SHRIMP U-Pb and muscovite and biotite ${ }^{40} \mathrm{Ar}-{ }^{39} \mathrm{Ar}$ dating show that the Paiku granite was emplaced during 22.2-16.2 Ma (average $19.3 \pm 3.9 \mathrm{Ma}$ ) and cooled rapidly to $350-400{ }^{\circ} \mathrm{C}$ at around $15.9 \mathrm{Ma}$. Whole-rock granite chemistry suggests the original granitic magma may have formed by muscovite dehydration melting of a protolith chemically similar to the High Himalayan Crystalline Sequence. Abundant calcareous metasedimentary rocks and minor garnet-staurolite-biotite-muscovite \pm andalusite schists record contact metamorphism by three granites that intruded intermittently into the Jurassic sediments between 18.5 and 15.3 Ma. Two stages of widespread penetrative ductile deformation, D1 and D2, can be defined. Microstructural studies of metapelites combined with geothermobarometry and pseudosection analyses yield $P-T$ conditions of $4.8 \pm 0.8 \mathrm{kbar}$ at $550 \pm 50^{\circ} \mathrm{C}$ during a non-deformational stage between $\mathrm{D} 1$ and $\mathrm{D} 2$, and 3.1-4.1 kbar at $530-575{ }^{\circ} \mathrm{C}$ during syn- to post-D2. The pressure estimates for the syn- to post-D2 growth of andalusite suggest relatively shallow (depth of $\sim 15.2 \mathrm{~km}$ ) extensional ductile deformation that took place within a shear zone of the South Tibetan Detachment System. Close temporal association between intrusion of the Malashan granite and onset of D2 suggests extension may have been triggered by the intrusion of the Malashan granite.
\end{abstract}

Key words: ${ }^{40} \mathrm{Ar}-{ }^{39} \mathrm{Ar}$ dating; contact metamorphism; extensional tectonics; North Himalayan gneiss domes; SHRIMP dating.

\section{INTRODUCTION}

The INDEPTH geophysical profile across southern Tibet revealed the presence of a mid-crustal lowvelocity zone interpreted as a partially molten crust that extends from $\sim 15$ to $\sim 50 \mathrm{~km}$ depth (e.g. Chen et al., 1996; Makovsky et al., 1996; Nelson et al., 1996; Hauck et al., 1998; Alsdorf \& Nelson, 1999). The southern margin of the partially molten zone is located $\sim 15 \mathrm{~km}$ north of the North Himalayan gneiss domes (NHGD) (Alsdorf et al., 1998), which form a discontinuous belt of medium-pressure/temperature $(P / T)$ type metamorphic rocks cored by deformed granite or granitic gneiss that can be traced across the Tethys
Himalaya at least from $78^{\circ} \mathrm{E}$ to $89^{\circ} \mathrm{E}$ (Hodges, 2000; Fig. 1a). Farther to the south, migmatitic sequences and pelitic schists beneath them in the Greater Himalaya are interpreted as a fossilized partial-melt zone formed during the Himalayan orogeny with a metamorphic age of 32-12 Ma (e.g. Schärer et al., 1986; Hodges et al., 1992, 1996; Edwards \& Harrison, 1997; Searle et al., 1997; Harrison et al., 1999; Simpson et al., 2000). Recently, several workers have proposed that the NHGD provide a window into a metamorphic core within the Tethys Himalaya that is the northward continuation of the Greater Himalaya and represents a previously hot, weak and partially molten middle crust beneath the Tibetan plateau (e.g. Hauck et al., 1998; 

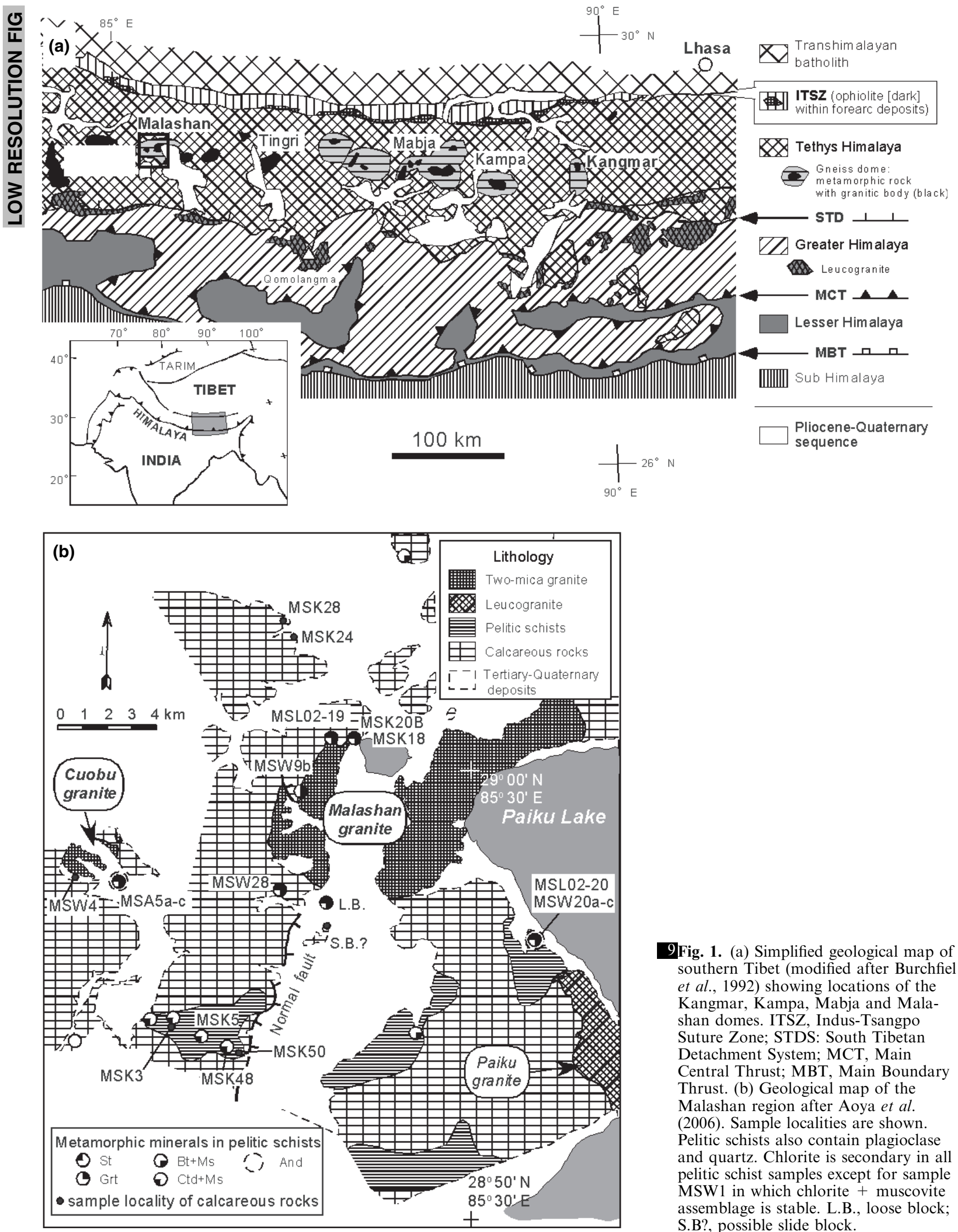

9Fig. 1. (a) Simplified geological map of southern Tibet (modified after Burchfiel et al., 1992) showing locations of the Kangmar, Kampa, Mabja and Malashan domes. ITSZ, Indus-Tsangpo Suture Zone; STDS: South Tibetan Detachment System; MCT, Main Central Thrust; MBT, Main Boundary Thrust. (b) Geological map of the Malashan region after Aoya et al. (2006). Sample localities are shown. Pelitic schists also contain plagioclase and quartz. Chlorite is secondary in all pelitic schist samples except for sample MSW1 in which chlorite + muscovite assemblage is stable. L.B., loose block; S.B?, possible slide block. 
Searle, 1999; Beaumont et al., 2001, 2004; Lee et al., 2006).

However, the NHGD have several variations that hinder simple interpretation of their evolution history. One important difference among the NHGD is the origin of their core. The cores of the NHGD are generally considered to be Cambrian gneiss (Schärer et al., 1986; Lee et al., 2000). Schists and migmatites surrounding them, such as in Kangmar (Burg et al., 1984; Chen et al., 1990; Lee et al., 2000), Mabja (Lee et al., 2004, 2006; Zhang et al., 2004; Lee \& Whitehouse, 2007) and Kampa (Quigley et al., 2006) domes are commonly intruded by Tertiary granites. Locally, such Tertiary granite has been interpreted to form the core to NHGD as in the case of the Malashan dome (Aoya et al., 2005, 2006) (Fig. 1a). Based on the observation that Tertiary granites are commonly muscovite-rich two-mica granites and the Cambrian gneiss cores are commonly poorer in muscovite, Watts et al. (2005) mapped the distribution of Tertiary granites in the NHGD using ASTER images. Mapping of the domes east of the Tingri dome using ASTER imagery crosschecked by field observation (Fig. 1a) suggests a systematic westward increase in the 'Tertiary granite' component within the domes (Watts et al., 2005). Characterization and dating of the Malashan dome (Fig. 1a), in particular the associated granites, is an important test of this proposed systematic change.

Another important difference among the NHGD is the depth of metamorphism and by implication the associated D2 extensional ductile deformational fabrics preserved in the metamorphic rocks surrounding the core. For example, pressure during the early stage of D2 deformation in Mabja dome is estimated at $\sim 8.0$ kbar for kyanite- and staurolite-zone rocks, and at $\sim 7.9$ kbar during the final stage of D2 deformation in sillimanite-zone rocks (Lee et al., 2004). In contrast, we will show that in Malashan pressure conditions were significantly lower during D2 deformation.

Nevertheless, the Kangmar, Kampa, Mabja and Malashan domes share several characteristics (Lee et al., 2004; Aoya et al., 2005, 2006; Quigley et al., 2006) including: (i) presence of two major penetrative deformational fabrics, D1 and D2, recorded in metasedimentary rocks around the core of the dome with development of the higher strain D2 structural fabrics towards the core; (ii) development of a strong D2 foliation in the outermost parts of the gneissic or granitic cores; (iii) an approximately $\mathrm{N}-\mathrm{S}$-trending stretching lineation associated with high-strain D2 foliation; and (iv) D1 characterized by the development of a moderately to steeply dipping $\mathrm{S} 1$ foliation as a consequence of $\mathrm{N}-\mathrm{S}$ shortening and vertical thickening. These similarities in the deformation history and kinematics of deformation imply that D1 and D2 have regional importance (Lee et al., 2004, 2006) although the age and the depth of deformation preserved may be different from dome to dome.
To understand the large-scale link between these domes, it is necessary to increase understanding of the age, geometry and kinematics of deformation of each individual dome. As a contribution to this, data are presented here that constrain the timing, depth and temperature conditions of the D2 extensional deformation in the Malashan dome. In particular, we report the pressure-temperature-deformation $(P-T-D)$ relationships observed in the contact metamorphic rocks in the Malashan dome and the results of zircon $\mathrm{U}-\mathrm{Pb}$ SHRIMP geochronological and muscovite and biotite ${ }^{40} \mathrm{Ar}-{ }^{39} \mathrm{Ar}$ thermochronological studies of the largest and previously undated, granite body within the Malashan area. The importance of the substantial fluid activity associated with the granite intrusions in thermally weakening the upper crust through numerous dyke formations during granite intrusion is also discussed.

\section{GENERAL GEOLOGY}

Three granite bodies surrounded by amphibolite facies metamorphic rocks are found in the Malashan region, southern Tibet (Burg et al., 1984; Aoya et al., 2005, 2006; Fig. 1) and the metamorphic/granitic complex as a whole is referred to as the 'Malashan dome'. The Malashan and Cuobu (Figs 1b, \& 2a,b) granites are compositionally similar two-mica granites (Aoya et al., 2005, 2006). However, the Malashan granite preserves a strong deformational fabric along its margin whereas the Cuobu granite only preserves a weak deformational fabric. The third granite, the Paiku leucogranite (Figs $1 \mathrm{~b} \& 2 \mathrm{c}, \mathrm{d}$ ), exhibits deformational fabrics that are intermediate between those of the Malashan and Cuobu granites (Aoya et al., 2006). Analysis of 1 ASTER images (Chikaraishi et al., pers. comm., 2004) shows that this leucogranite is continuous with a larger granite exposure on the eastern side of the Paiku Lake (Fig. 1a).

The sedimentary rocks hosting the granites are Jurassic in sedimentary age (Aoya et al., 2006) and, for the most part, weakly metamorphosed grey calcareous mudstone with locally intercalated metapelite. Overall, the metamorphic grade of the surrounding metasediments increases towards the granites. The highest grade pelitic rocks contain the assemblage garnet + staurolite + biotite + muscovite \pm andalusite. Kyanite- or sillimanite-bearing metasedimentary rocks and migmatites reported from Kangmar, Kampa and Mabja domes (cf. Lee et al., 2000, 2004, 2006; Quigley et al., 2006) were not observed in the Malashan area.

Two major ductile deformation events, D1 and D2, are recognized in the metasedimentary rocks in Malashan dome and summarized below based on Aoya et al. (2006). The dominant foliation, S2, developed in schist adjacent to the granites is broadly horizontal and is defined as the D2 foliation. S2 is most strongly developed in the region adjacent to the granites: strain 

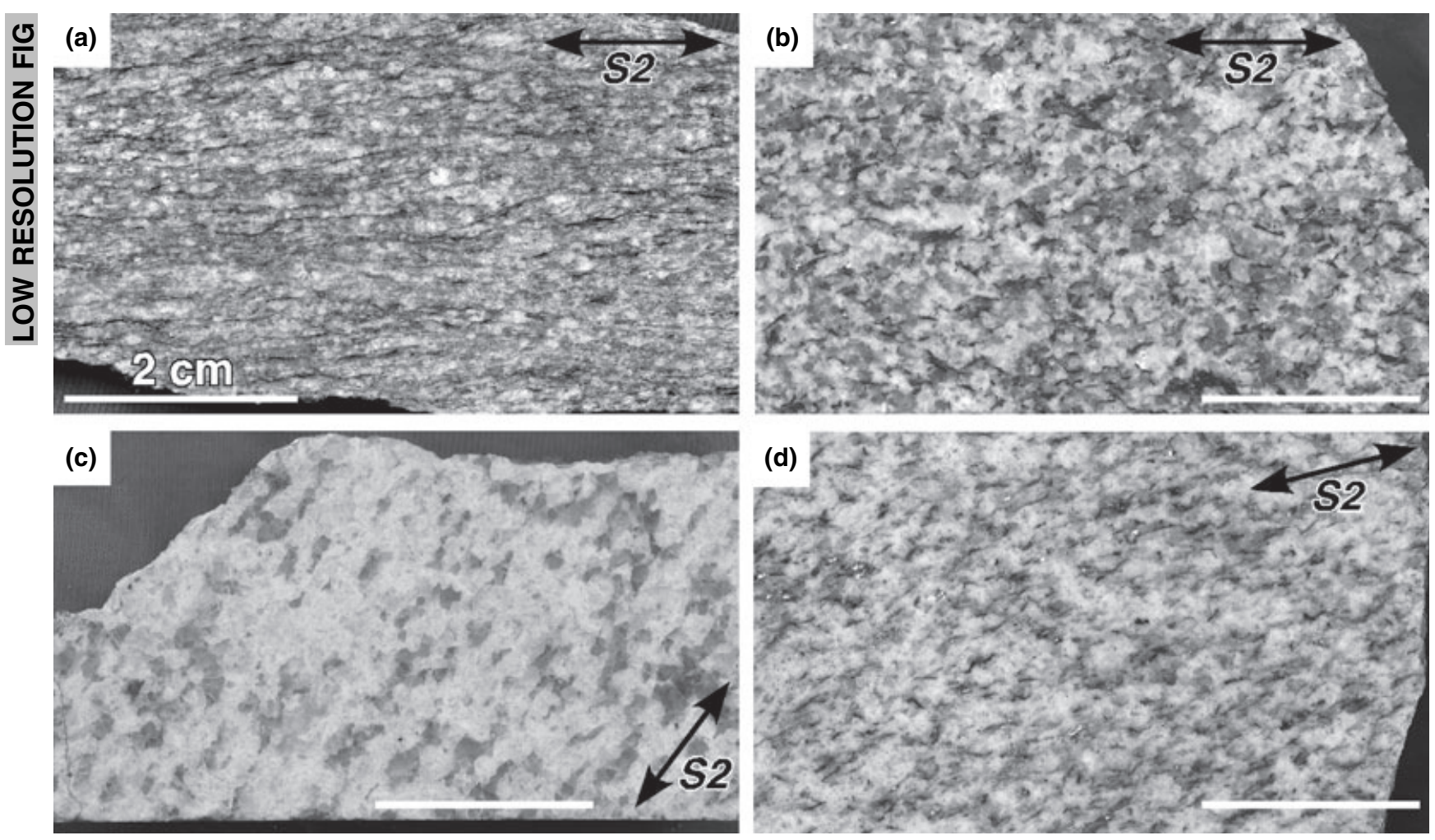

Fig. 2. Slab photographs of granites from the Malashan area. All samples were taken from peripheral parts of the granite bodies. White scale bar is $2 \mathrm{~cm}$. (a) Malashan granite (MSA12); (b) Cuobu granite (MSL4c); (c) Paiku leucogranite (MSW23); and (d) Paiku two-mica granite (MSL21).

associated with $\mathrm{S} 2$ decreases with distance from the granites. Among the three granite bodies, only the outermost part of the Malashan granite shares the well-developed S2 with the surrounding schists and is regarded as the core of the Malashan dome. The D2 stretching lineation (L2) trends N-S to NE-SW and is primarily defined by the alignment of iron oxide or hydroxide streaks associated with pyrite and locally developed pressure shadows of calcite around plagioclase grains in calcareous metasedimentary rocks. D2 is dominantly associated with top-to-the $\mathrm{N}$ shear sense indicators such as extensional cracks (or boudin necks) oblique to the foliation, vein sets representing asymmetric distribution of shortening and stretching quarters of bulk strain, asymmetry of lenses or clasts, rigid-body rotation of porphyroclastic plagioclase recognized by continuation of the internal S1 into external S2, oblique grain-shape fabrics of calcite grains and outcrop-scale shear bands. All these indicators are developed in calcareous metasedimentary rocks. An earlier deformation phase, D1, is defined by an S1 foliation folded by D2 folds and the D1 foliation is associated with a top-to-the $\mathrm{S}$ sense of shear.

Within the framework of the Himalayan orogeny, tectonic fabrics broadly dip north, and top-to-the S sense of shear have been correlated with a thrustrelated burial event and top-to-the $\mathrm{N}$ sense of shear have been correlated with STDS-related normal-sense exhumation (Aoya et al., 2005, 2006).

Chemically, the Cuobu and Malashan granites yield similar whole-rock compositions (Aoya et al., 2006) suggesting that these two granites were formed from similar protolith through similar processes. The intrusive relationship between the Cuobu granite and surrounding Jurassic metasedimentary rocks is documented by the presence of granitic dykes emanating from the main body (Aoya et al., 2006). SHRIMP $\mathrm{U}-\mathrm{Pb}$ dating of zircon indicated that the intrusion age of the Cuobu granite, which has to be younger than Jurassic, was recorded almost exclusively in uranium-rich rims which yielded ages of 26.0 13.7 Ma (average $18.6 \pm 2.8 \mathrm{Ma}$; Aoya et al., 2005). Analogous zonation is recorded in zircon of the Malashan granite and SHRIMP U-Pb geochronology on zircon suggests the granite has an emplacement age of 18.5-17.2 Ma (average 17.8 $\pm 1.1 \mathrm{Ma}$; Aoya et al., 2005). Muscovite and biotite ${ }^{40} \mathrm{Ar}-{ }^{39} \mathrm{Ar}$ thermochronology yielded $15.68 \pm 0.03$ and $15.27 \pm$ $0.06 \mathrm{Ma}$, respectively, for the Cuobu granite and $15.93 \pm 0.04$ and $15.50 \pm 0.06 \mathrm{Ma}$, respectively, for the Malashan granite (Aoya et al., 2005). These age constraints indicate that the Cuobu and Malashan granites intruded into Jurassic Tethyan sediments during the Miocene, and subsequently cooled to 
400-350 ${ }^{\circ} \mathrm{C}$ within a few million years following emplacement.

\section{U-PB SHRIMP GEOCHRONOLOGY ${ }^{40}$ AR- ${ }^{39}$ AR THERMOCHRONOLOGY OF THE PAIKU GRANITE}

$\mathrm{U}-\mathrm{Pb}$ SHRIMP geochronology on zircon and ${ }^{40} \mathrm{Ar}-{ }^{39} \mathrm{Ar}$ thermochronology on muscovite and biotite separated from the Paiku granite were carried out. Although the Paiku granite consists primarily of biotite-free leucogranite, a locally two-mica-bearing portion (sample MSL21; Fig. 2d) was selected for ${ }^{40} \mathrm{Ar}-{ }^{39} \mathrm{Ar}$ dating. Results of geochronological and thermochronological studies are shown in Figs 3 and 4 and Table 1.

Zircon grains from the Paiku granite commonly show dark uranium (U)-poor cores (120-3567 p.p.m.) and relatively bright U-rich rims (7603-12 661 p.p.m.) in backscattered electron images (Fig. 3). Twelve SHRIMP spot analyses of the dark cores yield a scattered distribution of ${ }^{238} \mathrm{U} /{ }^{206} \mathrm{~Pb}^{*}$ ages ranging from 2469 to $395 \mathrm{Ma}$ (Fig. 4a \& Table 1) with one Miocene age of $16.2 \mathrm{Ma}$ (Fig. 4b \& Table 1). The Miocene age core does not have inclusions of other minerals (Fig. 3), and yields the highest uranium content of 3567 p.p.m. $(\mathrm{Th} / \mathrm{U}=0.062)$. This suggests that zircon not only overgrew the existing grains at their rim but also newly nucleated during Miocene.

In contrast, four analyses of the bright uranium-rich rims yield Miocene ${ }^{238} \mathrm{U}^{206} \mathrm{~Pb}^{*}$ ages that range from 22.2 to $17.0 \mathrm{Ma}$ (Figs $3 \& 4 \mathrm{~b} \&$ Table 1 ). The relatively young rims and one uranium-rich core can be interpreted to represent the age of crystallization of zircon from the granitic melt. The high uranium nature of the inclusion-rich rim implies a potential Pb-loss and, therefore, the actual age could be a little older. Combining the young core and rim ages yields an average age of $19.3 \pm 3.9 \mathrm{Ma}$. This suggests that SHRIMP ages for three granites are within error and indistinguishable. However, judging from the well-defined SHRIMP age for the Malashan granite (18.5-17.2 Ma) and intrusion sequence constrained by the strength of D2 deformation which is in the decreasing order of the Malashan, the Paiku and the Cuobu granites, it is likely that the emplacement age of the Paiku and Cuobu granites are somewhat younger than the Malashan granite (e.g. Aoya et al., 2005).

The core ages range from $982 \pm 29$ to $248 \pm 5 \mathrm{Ma}$ for the Malashan granite, $1723 \pm 135$ to $298 \pm$ $24 \mathrm{Ma}$ for the Cuobu granite (Aoya et al., 2005) and $2469 \pm 115$ to $395 \pm 33 \mathrm{Ma}$ for the Paiku granite (Fig. 4). These can be the inherited ages from the protolith of granites.

Biotite from MSL21 yields a flat ${ }^{40} \mathrm{Ar}-{ }^{39} \mathrm{Ar}$ spectrum (MSWD $=1.34$ ) for the initial seven heating steps with a plateau age of $15.93 \pm 0.03 \mathrm{Ma}$. The final $\sim 10 \%$ of the spectrum exhibits slightly increasing ages with an associated drop in $\mathrm{K} / \mathrm{Ca}$ (Fig. 4c). Muscovite from

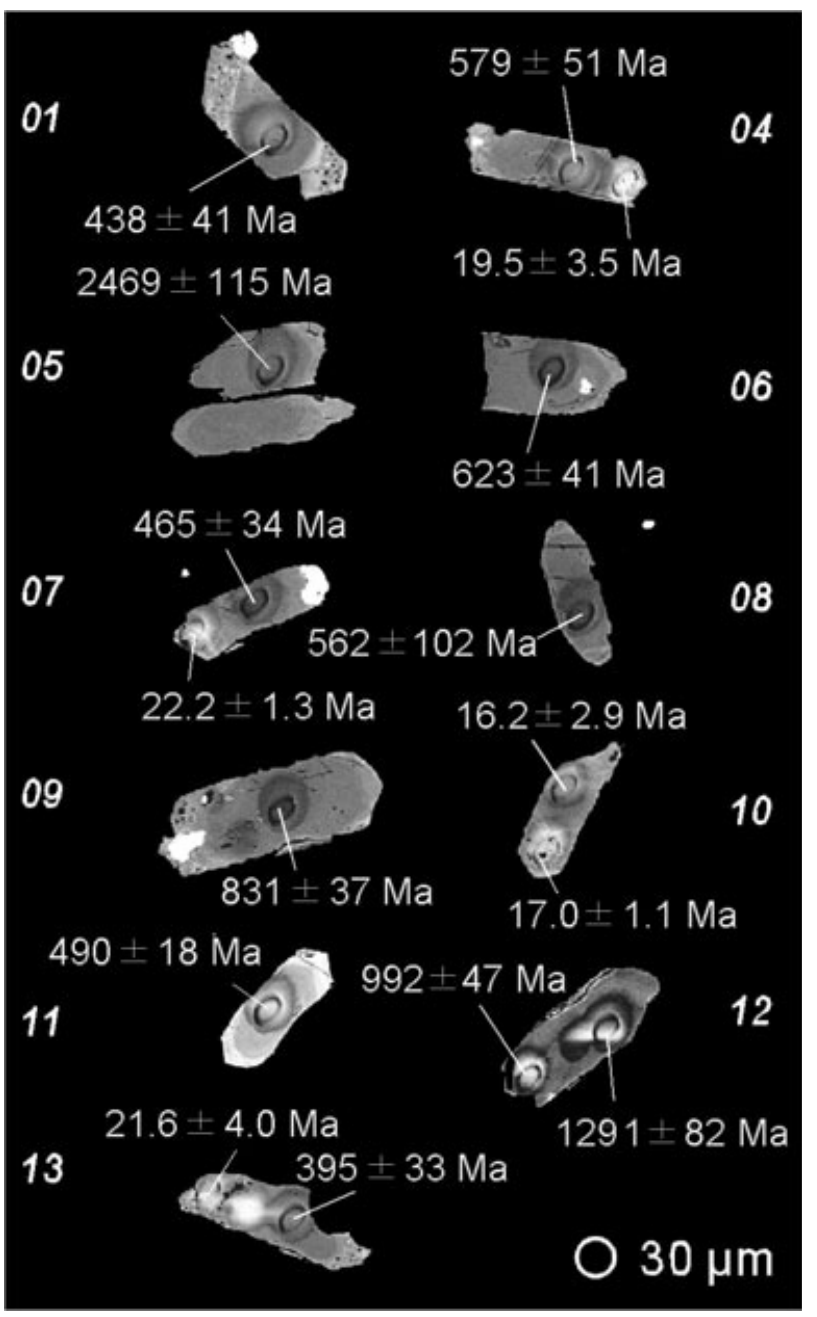

Fig. 3. Backscattered electron (BSE) images of zircon grains dated by the SHRIMP U-Pb method. ${ }^{238} \mathrm{U} /{ }^{206} \mathrm{~Pb}$ * age for each spot is also shown. Zircon grains were separated using a magnetic separator and heavy liquids. After handpicking and mounting into epoxy, the grains were polished to expose grain cross-sections and both cathode luminescence (CL) and BSE images were obtained. Analytical procedures of the U-Pb spot dating by SHRIMP II at Hiroshima University are described in Sano et al. (2000). A $1.3 \mathrm{nA} \mathrm{O}_{2}$ primary beam with accelerating voltage of $10 \mathrm{kV}$ was focused to sputter an area with a diameter of approximately $20 \mu \mathrm{m}$, and the positive secondary ions were extracted using $10 \mathrm{kV}$ voltage. Numbers written at the sides $8(01-13)$ correspond to the grain number of zircon used in Table 1.

sample MSL21 yields a flat ${ }^{40} \mathrm{Ar}-{ }^{39} \mathrm{Ar}$ spectrum for the first $\sim 80 \%$ of ${ }^{39} \mathrm{Ar}$ released that yields a plateau age of $15.93 \pm 0.04 \mathrm{Ma}$ and an MSWD of 1.15 (Fig. 4d). Like biotite, this muscovite also yields increasing apparent ages for the final part of the spectrum with associated decreasing $\mathrm{K} / \mathrm{Ca}$ values. Following McDougall \& Harrison (1999), nominal closure temperature values are assigned as 350 and $400{ }^{\circ} \mathrm{C}$ for biotite and muscovite respectively. MSL21 muscovite and biotite have identical plateau ages of $15.93 \mathrm{Ma}$ and suggest rapid cooling through $400-350{ }^{\circ} \mathrm{C}$. 

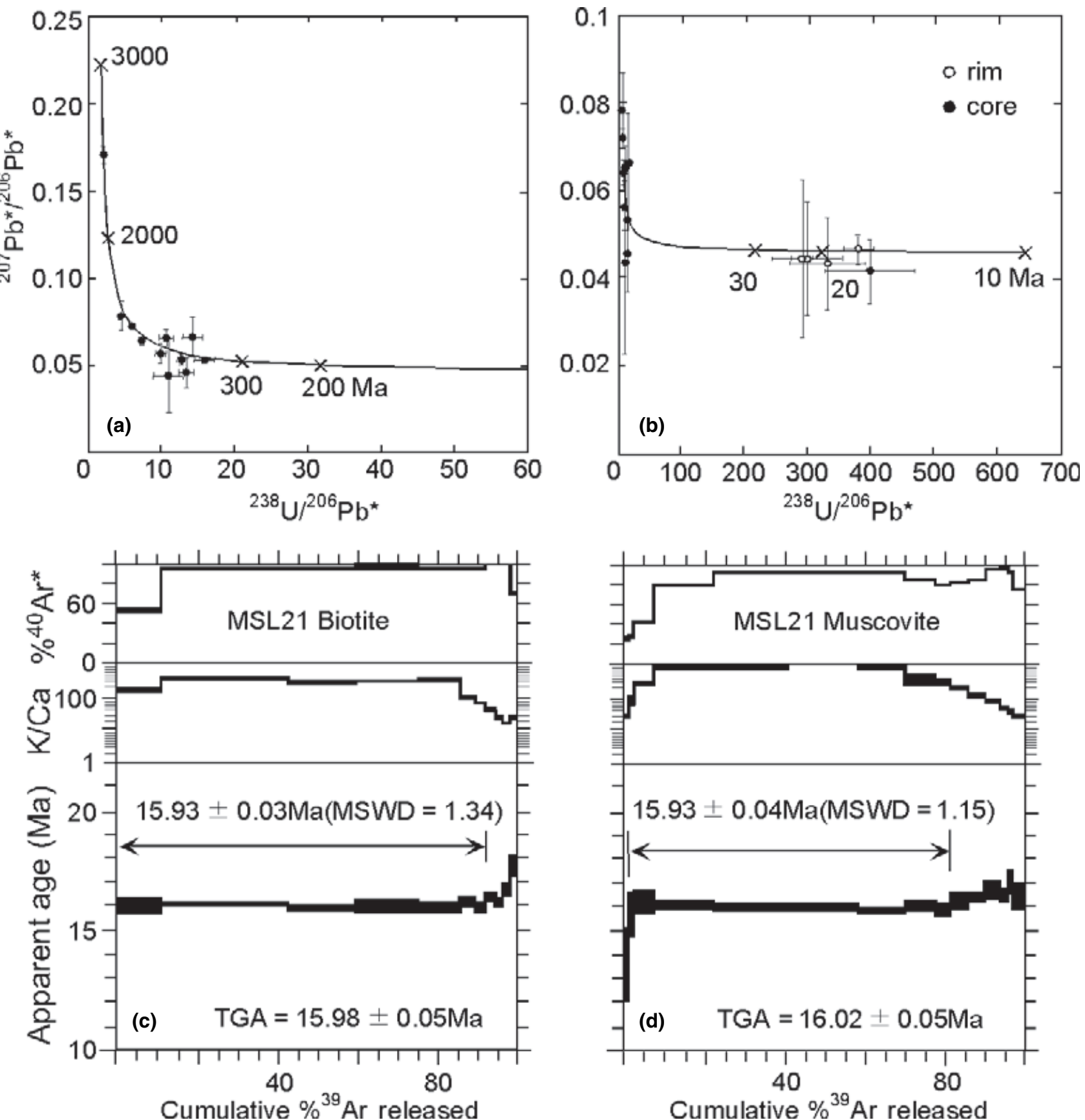

Fig. 4. (a, b) Tera-Wasserburg U-Pb concordia diagram for the Paiku granite with $95 \%$ confidence limits for the mean. $\mathrm{Pb} *$ is a corrected value for radiogenic $\mathrm{Pb}$ based on subtracting common $\mathrm{Pb}$ from the measured $\mathrm{Pb}$ assuming a composition based on the twostage evolution model of Stacey \& Kramers (1975). For comparison, ${ }^{238} \mathrm{U} /{ }^{206} \mathrm{~Pb}^{*}$ ages were calculated using both ${ }^{204} \mathrm{~Pb}$ and ${ }^{208} \mathrm{~Pb}$, and ${ }^{207} \mathrm{~Pb}$ corrections assuming that radiogenic ${ }^{207} \mathrm{~Pb} /{ }^{206} \mathrm{~Pb}$ is consistent with concordance. These U- $\mathrm{Pb}$ ages agree within analytical uncertainty, and here we adopt the correction based on ${ }^{208} \mathrm{~Pb}$. (b) High ${ }^{238} \mathrm{U} /{ }^{206} \mathrm{~Pb}^{*}$ value part of the same Tera-Wasserburg U-Pb concordia diagram as (a). (c, d) ${ }^{40} \mathrm{Ar}-{ }^{39} \mathrm{Ar}$ dating of mica separated from the Cuobu granite (sample MSL21). Age spectra, K/Ca and radiogenic yield diagrams for the dated (c) biotite and (d) muscovite. Plateau ages reported at 1 sigma. Muscovite and biotite separates were obtained by standard heavy liquid and magnetic techniques and used in ${ }^{40} \mathrm{Ar}^{-39} \mathrm{Ar}$ dating at New Mexico Geochronological Research Laboratory (NMGRL). Separates were loaded into machined Al discs and irradiated at Texas A\&M University. Mica was analysed by the incremental step-heating method and were heated within a double vacuum Mo resistance furnace.

Combining the above age constraints with the field observation that the Paiku granite possesses a deformational fabric that is intermediate in strength between the two Miocene granites (the Malashan and Cuobu granites; Aoya et al., 2006), we conclude that the Paiku granite intruded into the Jurassic sediments 
Table 1. U-Th- $\mathrm{Pb}$ isotopic compositions of zircons from the Paiku granite (sample MSL21). Spot number indicates 'grain number (01-13)' + 'core (c) or rim (r)'. For example, '01c' stands for 'core of the grain 01'.

\begin{tabular}{|c|c|c|c|c|c|c|c|c|c|c|}
\hline Spot no. & Core/rim & $\mathrm{U}$ (p.p.m.) & Th (p.p.m.) & $\mathrm{Th} / \mathrm{U}$ & ${ }^{204} \mathrm{~Pb} /{ }^{206} \mathrm{~Pb}$ & ${ }^{207} \mathrm{~Pb} /{ }^{206} \mathrm{~Pb}$ & ${ }^{208} \mathrm{~Pb} /{ }^{206} \mathrm{~Pb}$ & ${ }^{207} \mathrm{~Pb} /{ }^{206} \mathrm{~Pb}^{*}$ & ${ }^{238} \mathrm{U} /{ }^{206} \mathrm{~Pb}^{*}$ & ${ }^{238} \mathrm{U} /{ }^{206} \mathrm{~Pb}^{*}$ age \\
\hline $01 \mathrm{c}$ & Old core & 426 & 171 & 0.413 & $0.000010 \pm 0.000055$ & $0.0589 \pm 0.0011$ & $0.10971 \pm 0.01500$ & $0.06631 \pm 0.01163$ & $14.22 \pm 1.36$ & $438 \pm 41$ \\
\hline $04 \mathrm{c}$ & Old core & 1069 & 107 & 0.102 & $0.000101 \pm 0.000054$ & $0.0690 \pm 0.0017$ & $0.04067 \pm 0.01014$ & $0.06549 \pm 0.00491$ & $10.65 \pm 0.99$ & $579 \pm 51$ \\
\hline $05 \mathrm{c}$ & Old core & 348 & 69 & 0.204 & $0.000026 \pm 0.000009$ & $0.1698 \pm 0.0040$ & $0.05366 \pm 0.00466$ & $0.17082 \pm 0.00504$ & $2.14 \pm 0.12$ & $2469 \pm 115$ \\
\hline $06 \mathrm{c}$ & Old core & 120 & 46 & 0.397 & $0.000097 \pm 0.000054$ & $0.0669 \pm 0.0018$ & $0.14656 \pm 0.00464$ & $0.05672 \pm 0.00571$ & $9.86 \pm 0.68$ & $623 \pm 41$ \\
\hline $07 \mathrm{c}$ & Old core & 569 & 120 & 0.216 & $0.000031 \pm 0.000088$ & $0.0666 \pm 0.0029$ & $0.11853 \pm 0.01519$ & $0.04569 \pm 0.00870$ & $13.37 \pm 1.01$ & $465 \pm 34$ \\
\hline $08 \mathrm{c}$ & Old core & 226 & 81 & 0.359 & $0.000213 \pm 0.000070$ & $0.0693 \pm 0.0022$ & $0.17325 \pm 0.01076$ & $0.04361 \pm 0.02096$ & $10.98 \pm 2.08$ & $562 \pm 102$ \\
\hline $09 \mathrm{c}$ & Old core & 510 & 78 & 0.156 & $0.000023 \pm 0.000030$ & $0.0681 \pm 0.0022$ & $0.05712 \pm 0.00244$ & $0.06426 \pm 0.00280$ & $7.27 \pm 0.35$ & $831 \pm 37$ \\
\hline $11 \mathrm{c}$ & Old core & 338 & 108 & 0.328 & $0.000912 \pm 0.000422$ & $0.0698 \pm 0.0015$ & $0.14159 \pm 0.00317$ & $0.05339 \pm 0.00298$ & $12.66 \pm 0.48$ & $490 \pm 18$ \\
\hline $12 \mathrm{c}$ & Old core & 350 & 262 & 0.767 & $0.000026 \pm 0.000096$ & $0.0842 \pm 0.0025$ & $0.24047 \pm 0.01098$ & $0.07834 \pm 0.00860$ & $4.51 \pm 0.32$ & $1291 \pm 82$ \\
\hline $12 \mathrm{r}$ & Old core & 2408 & 49 & 0.021 & $0.000002 \pm 0.000015$ & $0.0726 \pm 0.0022$ & $0.00727 \pm 0.00059$ & $0.07221 \pm 0.00221$ & $6.01 \pm 0.31$ & $992 \pm 47$ \\
\hline $13 \mathrm{c}$ & Old core & 389 & 18 & 0.049 & $0.000238 \pm 0.000116$ & $0.0652 \pm 0.0010$ & $0.04588 \pm 0.00148$ & $0.05320 \pm 0.00137$ & $15.84 \pm 1.38$ & $395 \pm 33$ \\
\hline $10 \mathrm{c}$ & Young core & 3564 & 216 & 0.062 & $0.000316 \pm 0.000212$ & $0.0658 \pm 0.0041$ & $0.08143 \pm 0.01057$ & $0.04185 \pm 0.00724$ & $397.65 \pm 71.28$ & $16.2 \pm 2.9$ \\
\hline $04 \mathrm{r}$ & Young rim & 10512 & 1494 & 0.146 & $0.000068 \pm 0.000037$ & $0.0517 \pm 0.0075$ & $0.06691 \pm 0.00697$ & $0.04358 \pm 0.01048$ & $330.00 \pm 59.56$ & $19.5 \pm 3.5$ \\
\hline $07 \mathrm{r}$ & Young rim & 11244 & 220 & 0.020 & $0.002506 \pm 0.000793$ & $0.0789 \pm 0.0136$ & $0.09521 \pm 0.02533$ & $0.04474 \pm 0.01817$ & $290.02 \pm 16.94$ & $22.2 \pm 1.3$ \\
\hline $10 \mathrm{r}$ & Young rim & 7603 & 83 & 0.011 & $0.000409 \pm 0.000227$ & $0.0547 \pm 0.0026$ & $0.02385 \pm 0.00529$ & $0.04688 \pm 0.00342$ & $378.69 \pm 24.24$ & $17.0 \pm 1.1$ \\
\hline $13 r$ & Young rim & 12661 & 188 & 0.015 & $0.002752 \pm 0.000748$ & $0.0912 \pm 0.0091$ & $0.12582 \pm 0.01835$ & $0.04471 \pm 0.01284$ & $297.51 \pm 55.59$ & $21.6 \pm 4.0$ \\
\hline
\end{tabular}

soon after emplacement of the Malashan granite (18.517.2 Ma), and rapidly cooled reaching $400-350{ }^{\circ} \mathrm{C}$ by $15.93 \mathrm{Ma}$.

\section{CHEMICAL ANALYSES OF METAPELITES}

Whole-rock major element compositions of metapelites collected near the granites (Fig. 1b) were determined in order to evaluate the similarity of whole-rock compositions between metapelites, and to utilize the result in determining the appropriate whole-rock composition for pseudosection analyses. They were determined with the Rigaku simultaneous X-ray spectrometer system 3550 at Kyoto University (Goto \& Tatsumi, 1994). Powdered rock samples of metapelites were heated in an electronic furnace at $900{ }^{\circ} \mathrm{C}$ in order to decompose carbonaceous materials such as graphite, and their glass beads were utilized in the XRF analyses. Trace element compositions were determined with a Shimadzu SXF-1200 XRF spectrometer at Nagoya University. The results are summarized in Table 2.

Mineral compositions were determined by JEOL JXA-8900R at the National Institute of Advanced Industrial Science and Technology (AIST) and at Okayama University of Science (OUS), under $15 \mathrm{kV}$ acceleration voltage, $12 \mathrm{nA}$ probe current and with a beam diameter of 1-4 $\mu \mathrm{m}$. Natural and synthetic minerals were used as standards. Representative results of mineral analyses are shown in Table 3a for calcareous metasedimentary rocks and skarn, and in Table $3 \mathrm{~b}$ for metapelites. Ferric iron in garnet was estimated by the method of Droop (1987). Mineral abbreviations are after Kretz (1983) except for wiluite (Wil).

\section{CALCAREOUS METASEDIMENTARY ROCKS AND SKARNS AROUND GRANITES}

Calcareous metasedimentary rocks (samples MSK3 and MSK50) distal to the granites (Fig. 1b) commonly
Table 2. Major and trace element compositions of metapelites from the Malashan area. See Fig. 1b for the sample localities. MSK15 is a boulder from the contact aureole of the Malashan granite. See text for detailed analytical procedures.

\begin{tabular}{|c|c|c|c|c|c|c|}
\hline \multirow{2}{*}{$\begin{array}{l}\text { Adjacent pluton } \\
\text { Sample no. }\end{array}$} & \multirow{2}{*}{$\begin{array}{l}\text { Cuobu } \\
\text { MSA5c }\end{array}$} & \multicolumn{3}{|c|}{ Malashan } & \multicolumn{2}{|c|}{ Paiku } \\
\hline & & MSL02-19 & MSW28 & MSK15 & MSW20a & MSL02-20 \\
\hline $\mathrm{SiO}_{2}$ & 61.22 & 64.28 & 60.25 & 60.33 & 65.30 & 57.96 \\
\hline $\mathrm{TiO}_{2}$ & 0.99 & 0.89 & 1.31 & 1.12 & 0.86 & 1.17 \\
\hline $\mathrm{Al}_{2} \mathrm{O}_{3}$ & 20.97 & 19.29 & 26.16 & 23.93 & 18.60 & 25.54 \\
\hline $\mathrm{Fe}_{2} \mathrm{O}_{3}$ & 8.74 & 8.23 & 5.25 & 7.01 & 7.42 & 8.11 \\
\hline $\mathrm{MnO}$ & 0.10 & 0.10 & 0.08 & 0.09 & 0.17 & 0.09 \\
\hline $\mathrm{MgO}$ & 1.53 & 1.77 & 0.67 & 1.10 & 1.36 & 1.28 \\
\hline $\mathrm{CaO}$ & 2.78 & 1.29 & 1.64 & 1.14 & 2.54 & 0.70 \\
\hline $\mathrm{Na}_{2} \mathrm{O}$ & 1.30 & 1.04 & 0.34 & 0.47 & 1.85 & 0.44 \\
\hline $\mathrm{K}_{2} \mathrm{O}$ & 2.38 & 3.06 & 3.60 & 4.40 & 1.32 & 4.33 \\
\hline $\mathrm{P}_{2} \mathrm{O}_{5}$ & 0.16 & 0.09 & 0.13 & 0.10 & 0.14 & 0.14 \\
\hline Total & 100.17 & 100.04 & 99.43 & 99.70 & 99.55 & 99.74 \\
\hline $\mathrm{Cr}$ & 139 & 100 & 127 & 142 & 75 & 130 \\
\hline $\mathrm{Ga}$ & 26 & 24 & 33 & 30 & 23 & 34 \\
\hline $\mathrm{Zr}$ & 258 & 211 & 313 & 202 & 328 & 316 \\
\hline Th & 27 & 20 & 30 & 25 & 25 & 29 \\
\hline $\mathrm{Co}$ & 55 & 58 & 28 & 30 & 46 & 46 \\
\hline $\mathrm{Rb}$ & 152 & 180 & 173 & 179 & 99 & 262 \\
\hline $\mathrm{Nb}$ & 22 & 21 & 25 & 23 & 20 & 28 \\
\hline $\mathrm{Ni}$ & 29 & 24 & 18 & 17 & 36 & 40 \\
\hline $\mathrm{Sr}$ & 264 & 141 & 278 & 207 & 176 & 82 \\
\hline $\mathrm{Cu}$ & 16 & 35 & 5 & 8 & 0 & 25 \\
\hline $\mathrm{Y}$ & 42 & 35 & 37 & 35 & 37 & 47 \\
\hline $\mathrm{Ba}$ & 485 & 571 & 661 & 663 & 372 & 684 \\
\hline $\mathrm{Zn}$ & 77 & 104 & 102 & 83 & 93 & 129 \\
\hline $\mathrm{Pb}$ & 34 & 31 & 26 & 27 & 39 & 34 \\
\hline$X_{\mathrm{Mg}}$ & 0.26 & 0.30 & 0.20 & 0.24 & 0.27 & 0.24 \\
\hline
\end{tabular}

Major elements in wt $\%$ and trace elements in p.p.m.

contain pseudomorphs now composed of aggregates of calcite + dolomite $\left(X_{\mathrm{Mg}}=0.83-0.86\right)+$ muscovite + quartz (Fig. 5a), and the matrix is mainly composed of calcite + dolomite + quartz + muscovite \pm hematite.

On the other hand, the matrix of calcareous metasedimentary rocks proximal to the granites (samples MSK18, MSK24 and MSK28) (Fig. 1b) is mainly composed of calcite + plagioclase + chlorite $\left(X_{\mathrm{Mg}}=0.72-0.80\right) \pm$ biotite $\quad\left(X_{\mathrm{Mg}}=0.83-0.85\right)+$ quartz \pm hematite (Fig. 5b). Porphyroblasts now composed of aggregates of plagioclase (An36-51) + 


\begin{tabular}{|c|c|c|c|c|c|c|c|c|c|}
\hline \multirow{3}{*}{$\begin{array}{l}\text { Sample } \\
\text { No. } \\
\text { Mineral }\end{array}$} & \multirow{3}{*}{$\begin{array}{l}\text { MSK18 } \\
\begin{array}{c}3 \\
\text { Pl }\end{array}\end{array}$} & \multicolumn{2}{|c|}{ MSK24 (Malashan) } & \multicolumn{3}{|c|}{ MSW4 (Malashan) } & \multirow{3}{*}{$\begin{array}{c}\text { Sample } \\
\text { No. } \\
\text { Mineral }\end{array}$} & \multirow{3}{*}{$\frac{\text { MSW4 }}{49}$} & \multirow{3}{*}{$\begin{array}{l}\text { Table 3a. Representative mineral composi- } \\
\text { tions in the calcareous metasedimentary } \\
\text { rocks and skarn (sample MSW4) determined } \\
\text { by electron microprobe. }\end{array}$} \\
\hline & & 70 & 64 & 32 & 38 & 58 & & & \\
\hline & & $\mathrm{Bt}$ & $\mathrm{Chl}$ & Wiluite & $\mathrm{Pl}$ & Cpx & & & \\
\hline $\mathrm{SiO}_{2}$ & 55.28 & 39.84 & 28.35 & 36.51 & 57.40 & 50.56 & $\mathrm{SiO}_{2}$ & 39.23 & \\
\hline $\mathrm{TiO}_{2}$ & 0.00 & 0.81 & 0.02 & 2.09 & 0.00 & 0.03 & $\mathrm{TiO}_{2}$ & 0.63 & \\
\hline $\mathrm{Al}_{2} \mathrm{O}_{3}$ & 28.95 & 16.16 & 21.83 & 17.06 & 27.20 & 0.37 & $\mathrm{Al}_{2} \mathrm{O}_{3}$ & 19.91 & \\
\hline $\mathrm{Cr}_{2} \mathrm{O}_{3}$ & 0.01 & 0.20 & 0.00 & 0.00 & 0.08 & 0.03 & $\mathrm{Cr}_{2} \mathrm{O}_{3}$ & 0.16 & \\
\hline $\mathrm{FeO}$ & 0.04 & 6.35 & 8.43 & 4.44 & 0.09 & 19.49 & $\mathrm{Fe}_{2} \mathrm{O}_{3}^{\mathrm{a}}$ & 2.49 & \\
\hline $\mathrm{MnO}$ & 0.00 & 0.02 & 0.01 & 0.09 & 0.00 & 0.56 & $\mathrm{FeO}^{\mathrm{a}}$ & 2.93 & \\
\hline $\mathrm{MgO}$ & 0.00 & 20.54 & 26.86 & 1.12 & 0.00 & 5.61 & $\mathrm{MnO}$ & 0.34 & \\
\hline $\mathrm{CaO}$ & 10.75 & 0.31 & 0.08 & 34.66 & 9.05 & 23.45 & $\mathrm{MgO}$ & 0.07 & \\
\hline $\mathrm{Na}_{2} \mathrm{O}$ & 5.24 & 0.10 & 0.03 & 0.05 & 6.15 & 0.17 & $\mathrm{CaO}$ & 34.42 & \\
\hline $\mathrm{K}_{2} \mathrm{O}$ & 0.05 & 10.22 & 0.03 & 0.00 & 0.22 & 0.02 & Total & 100.18 & \\
\hline Total & 100.31 & 94.55 & 85.63 & 96.03 & 100.18 & 100.28 & $\mathrm{O}$ & 12 & \\
\hline $\mathrm{O}$ & 8 & 22 & 28 & 73.5 & 8 & 3 & $\mathrm{Si}$ & 2.99 & \\
\hline $\mathrm{Si}$ & 2.48 & 5.75 & 5.57 & 18.01 & 2.57 & 1.00 & $\mathrm{Ti}$ & 0.04 & \\
\hline $\mathrm{Ti}$ & 0.00 & 0.09 & 0.00 & 0.78 & 0.00 & 0.00 & $\mathrm{Al}$ & 1.79 & \\
\hline $\mathrm{Al}$ & 1.53 & 2.75 & 5.05 & 9.92 & 1.43 & 0.01 & $\mathrm{Cr}$ & 0.01 & \\
\hline $\mathrm{Cr}$ & 0.00 & 0.02 & 0.00 & 0.00 & 0.00 & 0.00 & $\mathrm{Fe}^{3+\mathrm{a}}$ & 0.14 & \\
\hline $\mathrm{Fe}^{2+}$ & 0.00 & 0.77 & 1.38 & 1.83 & 0.00 & 0.32 & $\mathrm{Fe}^{2+\mathrm{a}}$ & 0.19 & \\
\hline $\mathrm{Mn}$ & 0.00 & 0.00 & 0.00 & 0.04 & 0.00 & 0.01 & $\mathrm{Mn}$ & 0.02 & \\
\hline $\mathrm{Mg}$ & 0.00 & 4.41 & 7.86 & 0.83 & 0.00 & 0.16 & $\mathrm{Mg}$ & 0.01 & \\
\hline $\mathrm{Ca}$ & 0.52 & 0.05 & 0.02 & 18.32 & 0.43 & 0.49 & $\mathrm{Ca}$ & 2.81 & \\
\hline $\mathrm{Na}$ & 0.46 & 0.03 & 0.01 & 0.05 & 0.53 & 0.01 & Total & 8.00 & \\
\hline K & 0.00 & 1.88 & 0.01 & 0.00 & 0.01 & 0.00 & Analysis at & AIST & \\
\hline Total & 4.99 & 15.74 & 19.91 & 49.78 & 4.99 & 2.00 & & & \\
\hline$X_{\mathrm{Mg}}$ & & 0.85 & 0.85 & 0.31 & & 0.34 & & & \\
\hline An & 53 & & & & 44 & & & & \\
\hline Analysis at & AIST & AIST & AIST & AIST & AIST & AIST & & & \\
\hline
\end{tabular}

${ }^{\mathrm{a}}$ Calculated by the method of Droop (1987).

quartz \pm calcite with numerous tiny holes (Fig. 5b,c) are also present in this rock type, and long diameter of the porphyroblasts $\leq 5 \mathrm{~mm}$ at the contact with the Malashan granite. The composition of plagioclase varies from sample to sample and is intensively chemically-zoned, indicating it formed in the presence of abundant fluid. Calcareous metasedimentary rocks with such porphyroblasts commonly show boudinage structures. Their interboudin partitions are filled with calcite + quartz, which have been interpreted to have formed during the final stages of D2 (Aoya et al., 2006). Variably thick veins consisting of calcite + quartz are commonly observed within the metasediments around the Malashan pluton. These veins crosscut S1 and are boudinaged or folded by D2 depending on their orientation with respect to the principal axes of D2 strain (Fig. 5d,e). Therefore, these veins formed after D1 and before the end of D2.

A rare garnet-clinopyroxene skarn, characterized by garnet-rich and garnet-poor layers, was sampled (sample MSW4) from the contact between the Cuobu granite and surrounding metasediments (Figs $1 \mathrm{~b} \&$ 6a). The garnet-rich layers are composed of garnet $\left(\mathrm{Grs}_{74-87}\right.$ $\left.\mathrm{Adr}_{7-17} \mathrm{Alm}_{5-7} \mathrm{Sps}_{0-1}\right)+$ clinopyroxene $\left(X_{\mathrm{Mg}}=0.34\right.$ $0.44)+$ plagioclase (An44-55) + quartz + calcite. The garnet-rich layers are selectively boudinaged with boudin necks subperpendicular to the D2 stretching lineation (Fig. 6a; Aoya et al., 2006). The interboudin partitions are principally filled with plagioclase with minor calcite (cf. Aoya et al., 2006). Plagioclase in the boudin necks shows fine-scale chemical zoning from the core (An47) to the rim (An54) (Fig. 6b). The euhe- dral nature of the chemical zoning implies growth of plagioclase in a free space, possibly in a fluid. Garnet and clinopyroxene are chemically zoned, and garnet shows particularly fine-scale oscillatory chemical zoning in BSE images (Fig. 6c). The garnet-poor layers are composed of clinopyroxene + plagioclase + calcite + quartz. Plagioclase porphyroblasts with dusty cores are found in the garnet-poor layers (Fig. 6d). The core is mainly composed of calcic plagioclase (An83-86) intergrown with less calcic plagioclase (An38-61). The dusty plagioclase is hosted by the matrix plagioclase with fine, intense chemical zoning (Fig. 6d). Wiluite, which includes clinopyroxene crystals, is found at the boundary between the garnet-rich and garnet-poor layers (Fig. 6a \& Table 3a). Garnet is locally found growing along the grain boundaries of clinopyroxene + plagioclase dominant parts of the garnet-poor layers.

The systematic change of mineral paragenesis observed in calcareous metasediments as a function of distance from the granites as described above is consistent with the interpretation that metamorphic grade increases with proximity to the granites (cf. Aoya et al., 2006).

\section{METAPELITES AROUND GRANITES}

Weakly metamorphosed sedimentary rocks are found in the south-western part of the studied area, about $8 \mathrm{~km}$ distant from the Malashan granite where contact metamorphism is not evident (samples MSK5 and MSK48; Fig. 1b). In this region, pelitic 


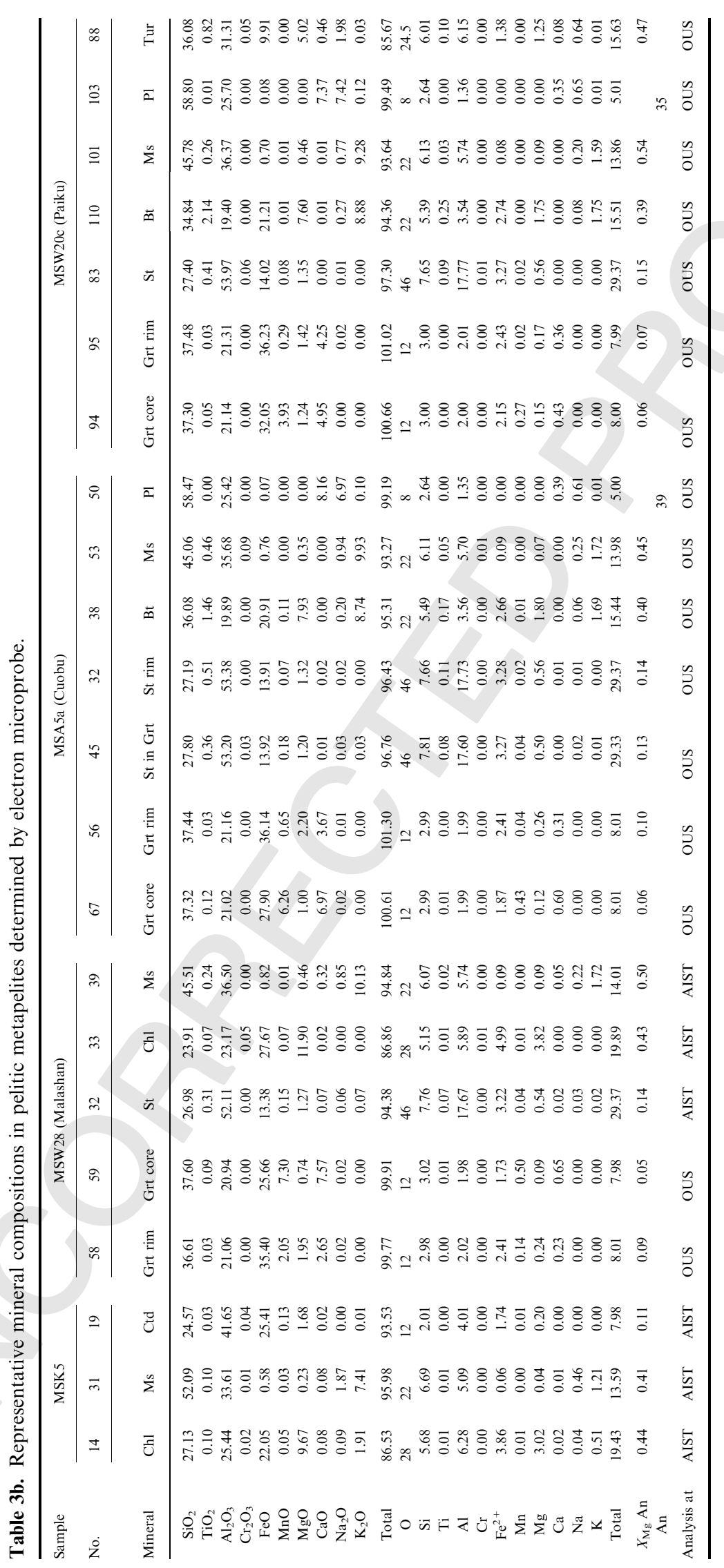




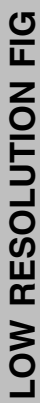
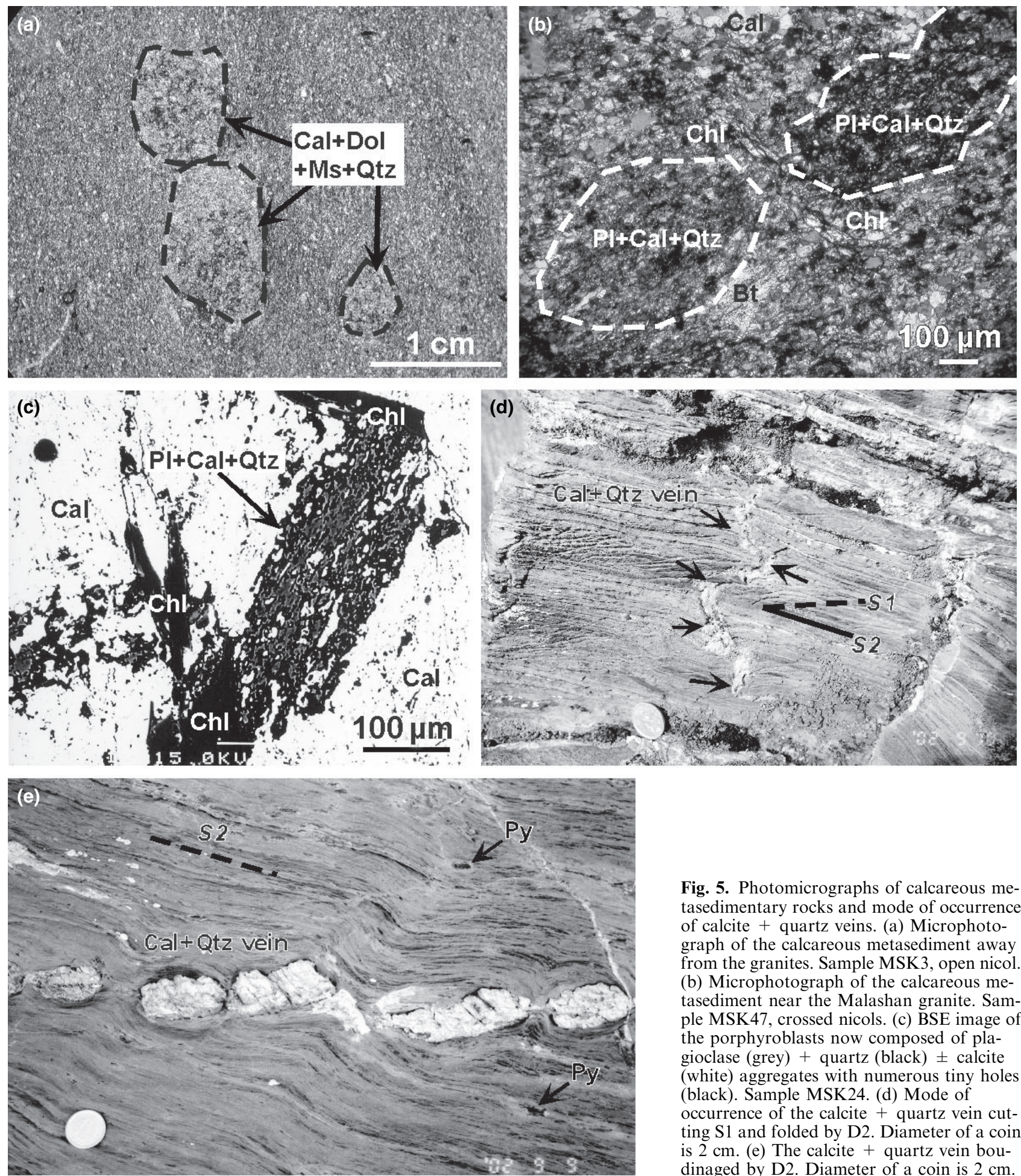

Fig. 5. Photomicrographs of calcareous metasedimentary rocks and mode of occurrence of calcite + quartz veins. (a) Microphotograph of the calcareous metasediment away from the granites. Sample MSK3, open nicol. (b) Microphotograph of the calcareous metasediment near the Malashan granite. Sample MSK47, crossed nicols. (c) BSE image of the porphyroblasts now composed of plagioclase (grey) + quartz (black) \pm calcite (white) aggregates with numerous tiny holes (black). Sample MSK24. (d) Mode of occurrence of the calcite + quartz vein cutting $\mathrm{S} 1$ and folded by D2. Diameter of a coin is $2 \mathrm{~cm}$. (e) The calcite + quartz vein boudinaged by D2. Diameter of a coin is $2 \mathrm{~cm}$.

rocks, primarily composed of muscovite + chlorite $\left(X_{\mathrm{Mg}}=0.44-0.46\right)+$ chloritoid $\left(X_{\mathrm{Mg}}=0.09-0.14\right)+$ quartz + tourmaline $\left(X_{\mathrm{Mg}}=0.41\right.$ at the core, 0.70 at the rim) + graphite, are intercalated with calcareous metasedimentary rocks. The foliation in these rocks is dominantly defined by graphite-rich layers. These rocks will be referred to as the 'chloritoid zone' rocks hereafter.

Higher grade metapelites with $\mathrm{Bt}+\mathrm{Ms}+\mathrm{Grt} \pm$ $\mathrm{St} \pm$ And $+\mathrm{Pl}+\mathrm{Qtz}+\mathrm{Tur}+\mathrm{Gr}+\mathrm{Ilm}+\mathrm{Ap}$ $+\mathrm{Zrn}$ are found in the vicinity of the granites. These rocks will be referred to as the 'staurolite zone' rocks 
(a) Wil
$\mathrm{Pl}+\mathrm{Cpx}+\mathrm{Cal}+\mathrm{Qtz}$
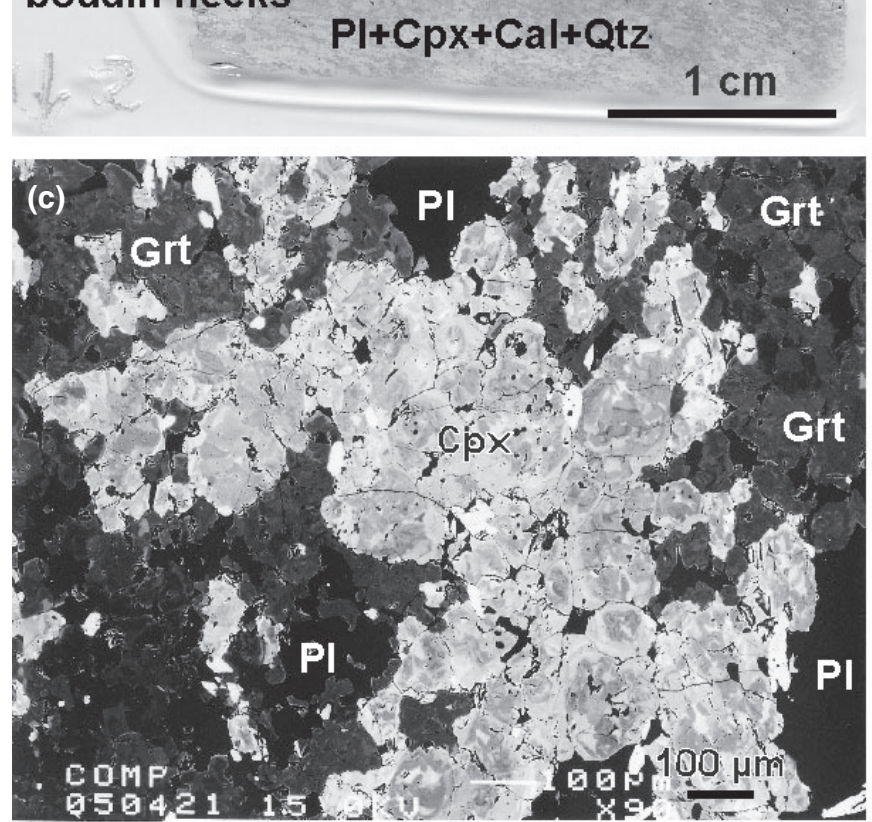
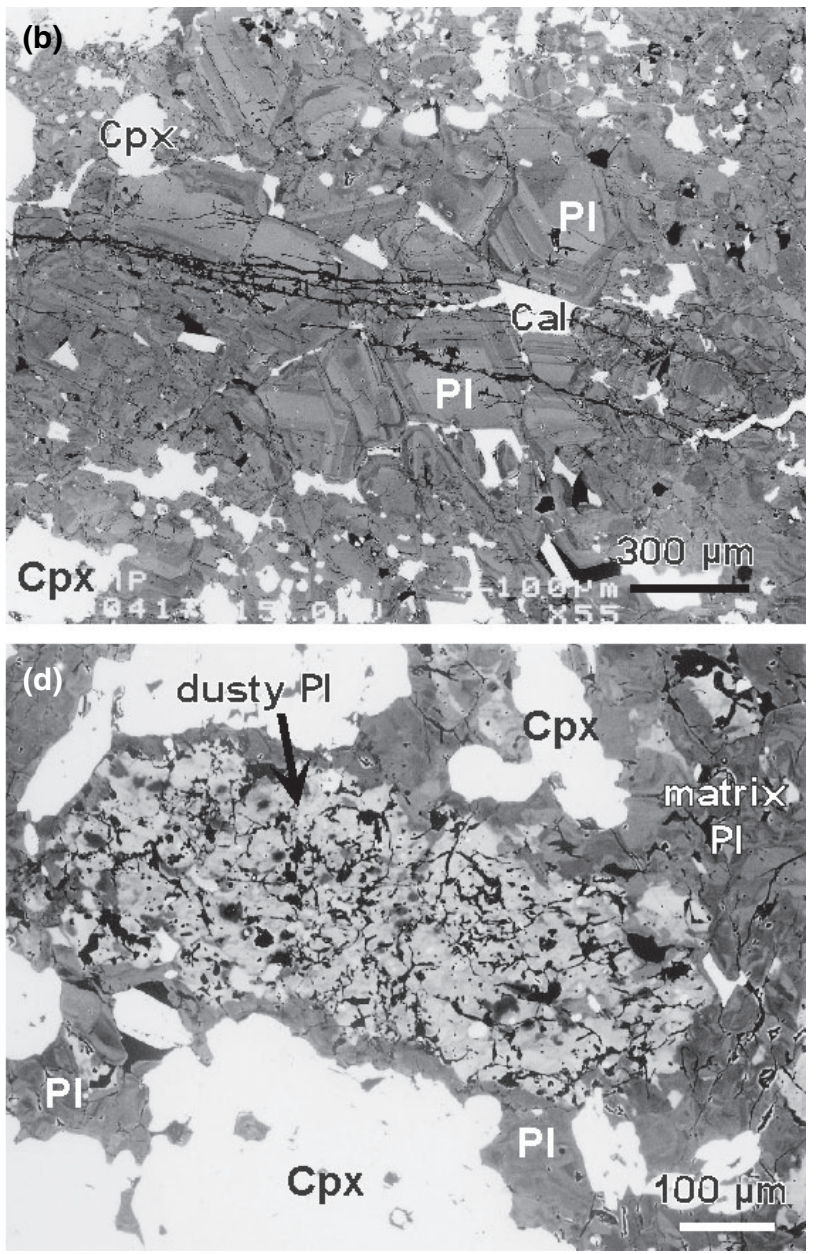

Fig. 6. Photomicrographs of the garnet-clinopyroxene skarn (sample MSW4). (a) Photograph of the entire thin section showing boudinage of garnet-rich layer sandwiched by the garnet-poor layers. Plagioclase + calcite fill the interboudin partitions. (b) BSE image of interboudin partitions. Plagioclase shows euhedral and intense chemical zoning. (c) BSE image of the garnet-rich layer. Both garnet and clinopyroxene show fine, intense chemical zoning indicative of crystallization in the presence of fluid. (d) BSE image of calcic, dusty plagioclase porphyroblast hosted by the less-calcic plagioclase with fine, intense chemical zoning. Dusty plagioclase itself is not homogeneous and locally albitic as shown by the dark grey colour within it. Black parts represent quartz.

hereafter. Seven staurolite-zone pelitic rocks from the vicinity of the granites were examined - three from near the Malashan, two from near the Cuobu and two from near the Paiku granites (Fig. 1b) - and are termed the Malashan metapelites, the Cuobu metapelites and the Paiku metapelites, respectively, in the following text. The staurolite-zone metapelites are aluminous and $\mathrm{Fe}$-rich, with $X_{\mathrm{Mg}}$ ranging from 0.20 to 0.30 (Table 3b). The $\mathrm{Al}_{2} \mathrm{O}_{3}-\mathrm{FeO}-\mathrm{MgO}-\mathrm{K}_{2} \mathrm{O}$ plot of the whole-rock compositions of the andalusite-bearing Cuobu and Paiku metapelites and the andalusite-free Malashan metapelites all fall within And-Ms-Bt-St fields, indicating that the absence of andalusite in the Malashan metapelites (Fig. 1b) is not controlled by the difference in whole-rock composition (Fig. 7), but reflects the difference in $P-T$ evolution between the Malashan metapelites and the Cuobu and Paiku metapelites. Note that elimination of 'relic' garnet (see description of metapelites below) from the stable mineral assemblage shifts the effective bulk composition away from garnet towards the And-Ms$\mathrm{Bt}-\mathrm{St}$ fields, which is consistent for the interpretation above.

The result of X-ray elemental mapping of garnet from metapelites around the three plutons (e.g. Fig. 8) shows that garnet preserves relatively sharp growthzoning, suggesting that the effect of intracrystal chemical diffusion postdating its formation is negligible.

\section{The Malashan metapelites}

The descriptions below focus on three samples MSW28, MSW9b and MSK20B (Fig. 1) - all associated with the Malashan granite. Andalusite and $\mathrm{K}$-feldspar are not found in any of the Malashan metapelites. The S1 foliation, defined by alignment of muscovite + biotite, is the dominant deformational 


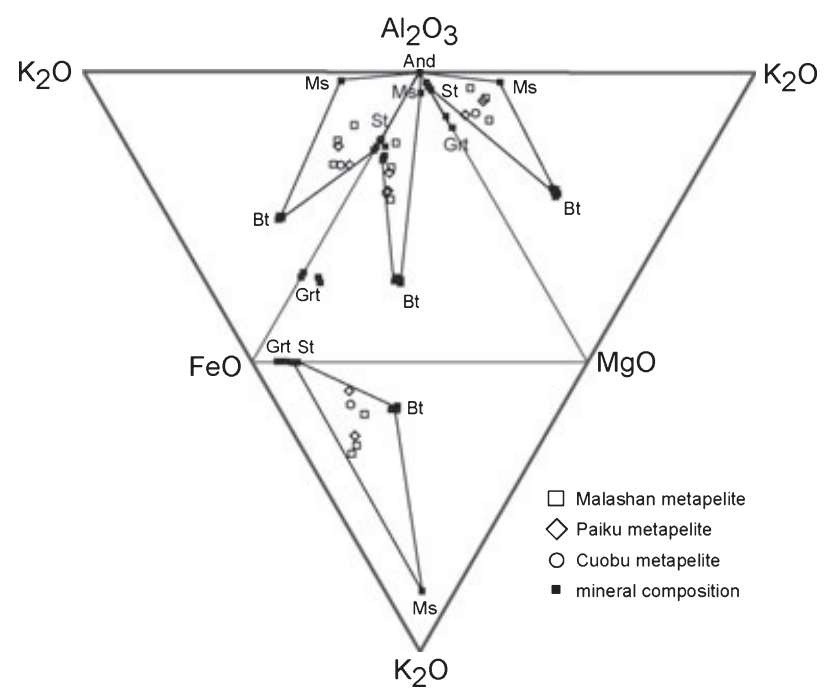

Fig. 7. $\mathrm{Al}_{2} \mathrm{O}_{3}-\mathrm{FeO}-\mathrm{MgO}-\mathrm{K}_{2} \mathrm{O}$ plot of the Malashan metapelite whole-rock composition and the compositions of biotite, muscovite, staurolite and garnet from the Cuobu metapelite determined by electron microprobe analyses. A similar plot was also constructed using the mineral compositions of the Paiku and Malashan metapelites, and the configuration is confirmed to be the same as this figure.

fabric in sample MSW28 (Figs 1b \& 9a). The S1 foliation is folded by weakly developed D2 folds (F2), and F2 axial planes are weakly developed at high angles to the $\mathrm{S} 1$ foliation (Fig. 9a). Staurolite $\left(X_{\mathrm{Mg}}=0.13-0.14\right)$ overgrows both F1 (Fig. 9b,c) and F2 folds. Strain shadows are not developed adjacent to staurolite in the directions of external S1 (Fig. 9b-e), suggesting that staurolite grew post-D1. The curved internal foliation of staurolite is continuous with the external S1 (Fig. 9d,e), indicating that the internal fabric is S1. The internal S1 continues outwards into the curved segment folded by $\mathrm{F} 2$ at the rim of the staurolite (Fig. 9d,e). Development of F2 folds is locally hindered by the presence of staurolite (Fig. 9f), suggesting that staurolite was already present in sample MSW28 when D2 started. These features indicate that growth of staurolite started during a non-deformational period after D1 and continued until syn-D2. Inclusion trails in staurolite are chiefly defined by the alignment of graphite, quartz and tourmaline, and scarce muscovite and biotite.

In contrast to staurolite, garnet $\left(X_{\mathrm{Mg}}=0.05\right.$ and $X_{\mathrm{Grs}}=0.22$ at the core, $X_{\mathrm{Mg}}=0.09$ and $X_{\mathrm{Grs}}=0.08$ at the rim, where $X_{\mathrm{Grs}}=\mathrm{Ca} /[\mathrm{Fe}+\mathrm{Mn}+\mathrm{Mg}+$ $\mathrm{Ca}$ ) commonly has strain shadows developed subparallel to S1 (Fig. 9a,g,h). In addition, hinges of D1 isoclinal folds are locally preserved in strain shadows of garnet (Fig. 9h). These textures indicate that garnet growth was syn-D1. Mica-rich veins cut S1 and are folded more weakly by the same D1 folds (shown by the arrows in Fig. 9g) indicating vein emplacement during D1 deformation. The vein is also overgrown by the staurolite (Fig. 9g). These textures also suggest

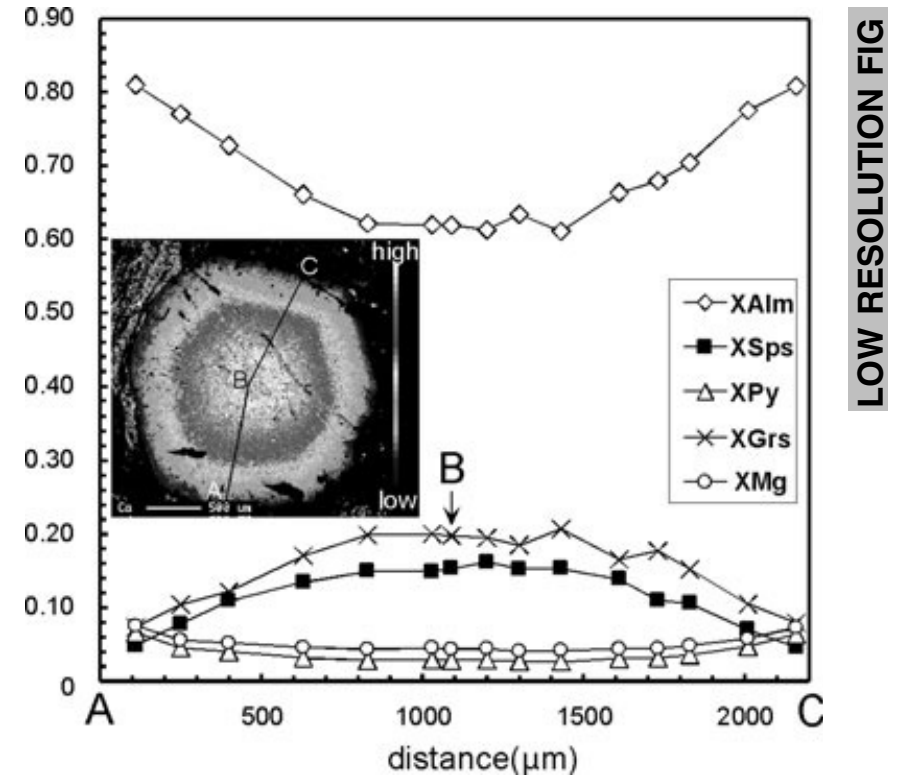

Fig. 8. An example of the X-ray mapping of garnet from the Malashan metapelite in terms of $\mathrm{Ca}$, and the chemical zoning profile along the lines connecting A, B and C shown in the X-ray mapping. Note that the concentric chemical zoning reflecting the euhedral shape of the garnet and rim-ward decrease in grossular content is well preserved. Sample MSW28. Alm, almandine [proportion of almandine component is calculated by $\mathrm{Fe}$ / $(\mathrm{Fe}+\mathrm{Mn}+\mathrm{Mg}+\mathrm{Ca})]$; Py, pyrope; Grs, grossular; Sps, spessartine.

activity of fluids during D1 deformation. Secondary chlorite $\left(X_{\mathrm{Mg}}=0.43-0.45\right)$ overgrows $\mathrm{S} 1$ and is commonly formed subparallel to the axial plane of D2 folds (Fig. 9i) suggesting it grew after D1, but by the end of D2.

Sample MSW9b (Fig. 1b) contains abundant tourmaline aligned within S2, but lacks staurolite. The abnormal abundance and intense chemical zoning of tourmaline (Fig. 9j) suggest its formation during the infiltration of boron-bearing fluid (e.g. London \& Manning, 1995). Tourmaline is accompanied by strain shadows that are developed within S2 and is locally boudinaged by $\mathrm{D} 2$. This suggests that tourmaline growth was pre- or syn-D2. Garnet rims were locally replaced mainly by muscovite with minor tourmaline, also implying infiltration of a boron-bearing aqueous fluid.

Sample MSK20B (Fig. 1b) possesses a well-developed S2 foliation, defined by alignment of muscovite + biotite $\left(X_{\mathrm{Mg}}=0.46-0.51\right)$. Based on inclusion patterns, staurolite $\left(X_{\mathrm{Mg}}=0.13-0.19\right)$ has distinct cores and rims. Most of the staurolite rims are inclusion free, and inclusion trails in the core are discontinuous with, and at a high angle to, the external S2 (Fig. 9k). This observation suggests that the foliation included in the staurolite core is mostly an older S1. However, locally, the inclusion trail in thin rims is continuous with the external S2 (Fig. 91), suggesting that the staurolite rim grew syn-S2. 
Garnet shows textural sector zoning, inclusion trails that are not continuous with the matrix foliation S2, and is commonly accompanied by D2 strain shadows (Fig. 9m). These observations are consistent with the observation of MSW28 where the garnet growth is deduced to have been syn-D1. Chemical zoning of garnet is Mn-bell shaped with rim-ward decrease in the grossular content $\left(X_{\mathrm{Grs}}=0.20\right.$ at the core and 0.08 at the rim) (Fig. 8), and $X_{\mathrm{Mg}}$ value slightly increases from the core $\left(X_{\mathrm{Mg}}=0.05\right)$ to the $\operatorname{rim}\left(X_{\mathrm{Mg}}=0.11\right)$. Plagioclase in the matrix has the composition of An33-38.

\section{The Cuobu metapelites}

The Cuobu metapelite samples were collected from boulders in the vicinity of the granite body. Two samples, MSA5a and MSA5b, are described below. Foliation within the metapelite is defined by the alignment of muscovite + biotite $\left(X_{\mathrm{Mg}}=0.40-0.42\right)$. Inclusion trails in staurolite $\left(X_{\mathrm{Mg}}=0.12-0.15\right)$ indicate distinct cores and rims. Trails exposed within the rim are developed subparallel to and continuous with the external matrix foliation, whereas those at the core define nearly straight lines and are at high angle to the rim inclusion trails. These microstructures are compatible with the deformation-growth relationships derived from the Malashan and Paiku samples if the external foliation is S2 and the internal straight foliation is S1. Therefore, it is concluded that the main foliation developed in MSA5a and MSA5b is $\mathrm{S} 2$.

Staurolite $\left(X_{\mathrm{Mg}}=0.13\right)$ is rarely included in the garnet rim (Fig. 10a). The chemical composition of the included staurolite resembles that of staurolite core in the rock matrix (Fig. 11), suggesting that garnet growth and entrapment of the staurolite inclusion probably occurred before staurolite-rim formation, that is, before D2. Therefore, we conclude that growth of garnet continued during a non-deformational period between D1 and D2 in the Cuobu metapelites. Garnet is commonly texturally sectorzoned in the core and replaced by biotite and plagioclase at the rim. These features make it difficult to constrain the timing of garnet formation. Where observable, inclusion trails in the garnet rim are not continuous with the matrix foliation. Chemical zoning of garnet is Mn-bell shaped with rim-ward decrease in grossular content $\left(X_{\mathrm{Grs}}=0.21\right.$ at the core and 0.09 at the rim) and rim-ward increase in $X_{\mathrm{Mg}}$ value $(0.05-$ $0.11)$.

Andalusite is present as porphyroblasts, a replacement of staurolite and biotite, and as a replacement of mica-rich layers. Porphyroblasts of andalusite, or type I andalusite, contain cores that commonly show sectorzoning represented by the concentration of inclusion minerals at the sector boundaries. These inclusion trails curve at the rim and locally continue into external S2 (Fig. 10b), implying growth of andalusite rim during D2.
Type II andalusite, along with biotite, replaces part of staurolite. In the case of the Cuobu metapelites, both the type II andalusite and fine-grained biotite grains that replace staurolite are randomly-oriented. Biotite is much more abundant in andalusite than in the staurolite (Fig. 10c), indicating that andalusite + biotite are the product of staurolite breakdown. The composition of relic staurolite inclusions in andalusite yields lower $X_{\mathrm{Mg}}$ and higher Ti than matrix staurolite (Fig. 11). Randomly oriented biotite implies that both growth of biotite and andalusite II are postD2.

Type III andalusite selectively replaces mica-rich layers; biotite grains that define S2 remain in the andalusite and are continuous with the matrix foliation (Fig. 10d). Muscovite was not observed within type III andalusite. These microstructures suggest that formation of type III andalusite occurred simultaneously with or after D2 by consuming muscovite.

Plagioclase porphyroblasts have dusty inclusion-rich cores and inclusion-poor rims. The straight inclusion trails at the core are at high angle to, and discontinuous with, the external S2 (Fig. 10e), suggesting that the core inclusion trails represent an S1 foliation and that the core formed during a non-deformational period between D1 and D2. Such plagioclase porphyroblasts display D2 strain shadows. In addition, there is an increase in anorthite content from the core (An33-36) to the rim (An39-40). Smaller matrix plagioclase grains also show an increase in anorthite content from An46 at the core to An50 at the rim (Fig. 10e).

Biotite exhibits an inclusion-rich core and inclusion-poor rim. The straight inclusion trails at the core are at high angle to, and discontinuous with, the external S2 (Fig. 10f), suggesting that the straight inclusion trail is a $\mathrm{S} 1$ foliation and the biotite core formed during a non-deformational period between D1 and D2.

K-feldspar is absent. Tourmaline $\left(X_{\mathrm{Mg}}=0.42-\right.$ 0.64 ) is found in the matrix aligned along S2 or as inclusions in andalusite, staurolite, biotite and plagioclase.

\section{The Paiku metapelites}

Four metapelite samples, MSL02-20 and MSW20a, b and $\mathrm{c}$, were collected adjacent to the Paiku granite. These four samples are all from the same locality and show similar features.

Inclusion trails in garnet porphyroblasts are commonly discontinuous with the external matrix S2 foliation. Garnet is commonly texturally sector-zoned in the core, and chemical zoning is Mn-bell shaped with a rim-ward decrease in grossular content $\left(X_{\mathrm{Grs}}=0.14\right.$ at the core and 0.11 at the rim) and a rim-ward increase in $X_{\mathrm{Mg}}$ value (0.06-0.08).

Some staurolite grains show two stages of discontinuous inclusion trails defining a core and a thin rim, whereas other grains only show one stage, with no rim 

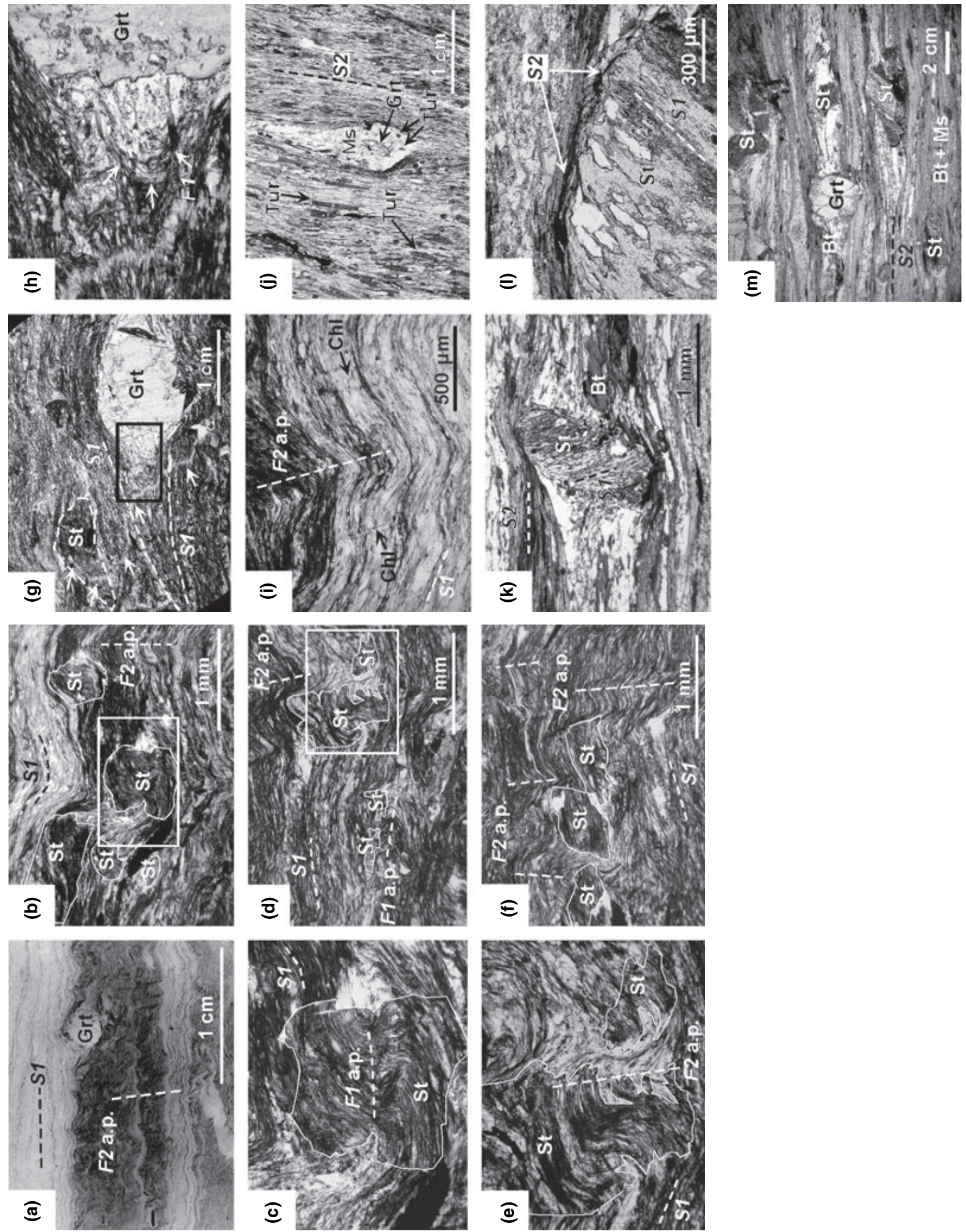


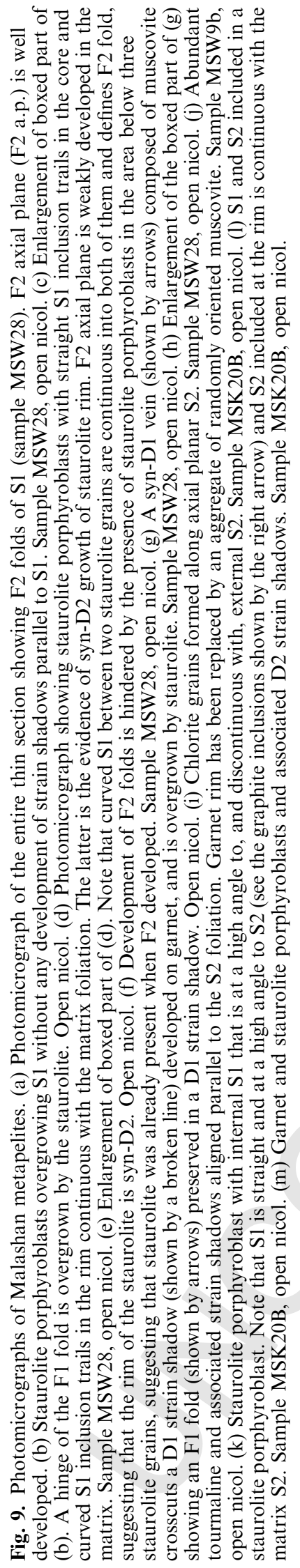

developed. In some of the staurolite grains, the inclusion trails in the rim are continuous with matrix S2 foliation. These grains also display D2 strain shadows. These textures are interpreted as indicating that the

2 staurolite rim grew during D2 (Fig. 15). Locally staurolite grains are partially replaced by andalusite + biotite similar to the observations in the Cuobu metapelites.

Andalusite is found as porphyroblasts (andalusite I), replacing part of staurolite (andalusite II) or selectively replacing mica-rich layers (andalusite III). Porphyroblastic andalusite I is locally boudinaged along S2 (Aoya et al., 2006; Fig. 12a-c), indicating that the formation of this type of andalusite occurred before the cessation of D2. Such deformed andalusite grains do not include randomly oriented biotite grains. In addition, microtextures suggest a genetic relationship between the different types of andalusite (Fig. 12). Staurolite adjacent to andalusite I is replaced by andalusite II + biotite intergrowth and, importantly, andalusite I and II exhibit simultaneous extinction (Fig. 12a,b); that is, the rims of andalusite I and II are continuous. Andalusite I rims also show syn-D2 deformation tails (Fig. 12a,c). These observations suggested that andalusite II grew simultaneously with the rim of andalusite I during D2. This interpretation is further supported by the microstructure shown in Fig. 12c. Here, andalusite II + biotite intergrowth is developed in between staurolite and andalusite I, forming part of a pullapart structure. This texture shows that andalusite II + biotite intergrowth was formed during the final stage of growth of andalusite I during D2 deformation. Matrix andalusite III includes 'patchy' biotite crystals (Fig. 12d,e), a texture not found in the matrix biotite (Fig. 12e). This patchy texture closely resembles the andalusite II + biotite intergrowth pattern and possibly the replacement product after staurolite. As we interpreted the formation of andalusite III in the Cuobu metapelites, Paiku andalusite III grew simultaneously with or after D2 by consuming muscovite (Fig. 12e). Based on our observations of andalusite in the Cuobu and Paiku metapelites, the striking difference between the two regions is that there is a genetic relationship between different types of andalusite in the Paiku metapelites.

Some large biotite grains in the matrix have straight inclusion trails of S1 within the core. The inclusion trails curve at the rim are locally continuous with the matrix S2. These textures indicate that the biotite core grew during a non-deformational period between D1 and D2, and the rim grew during D2 (Fig. 12e).

Plagioclase porphyroblasts have dusty inclusion-rich cores and inclusion-poor rims, and display D2 strain shadows. The core includes straight inclusion trails (the S1 foliation) that are at a high angle to, and discontinuous with, the external S2. We suggest, there- 

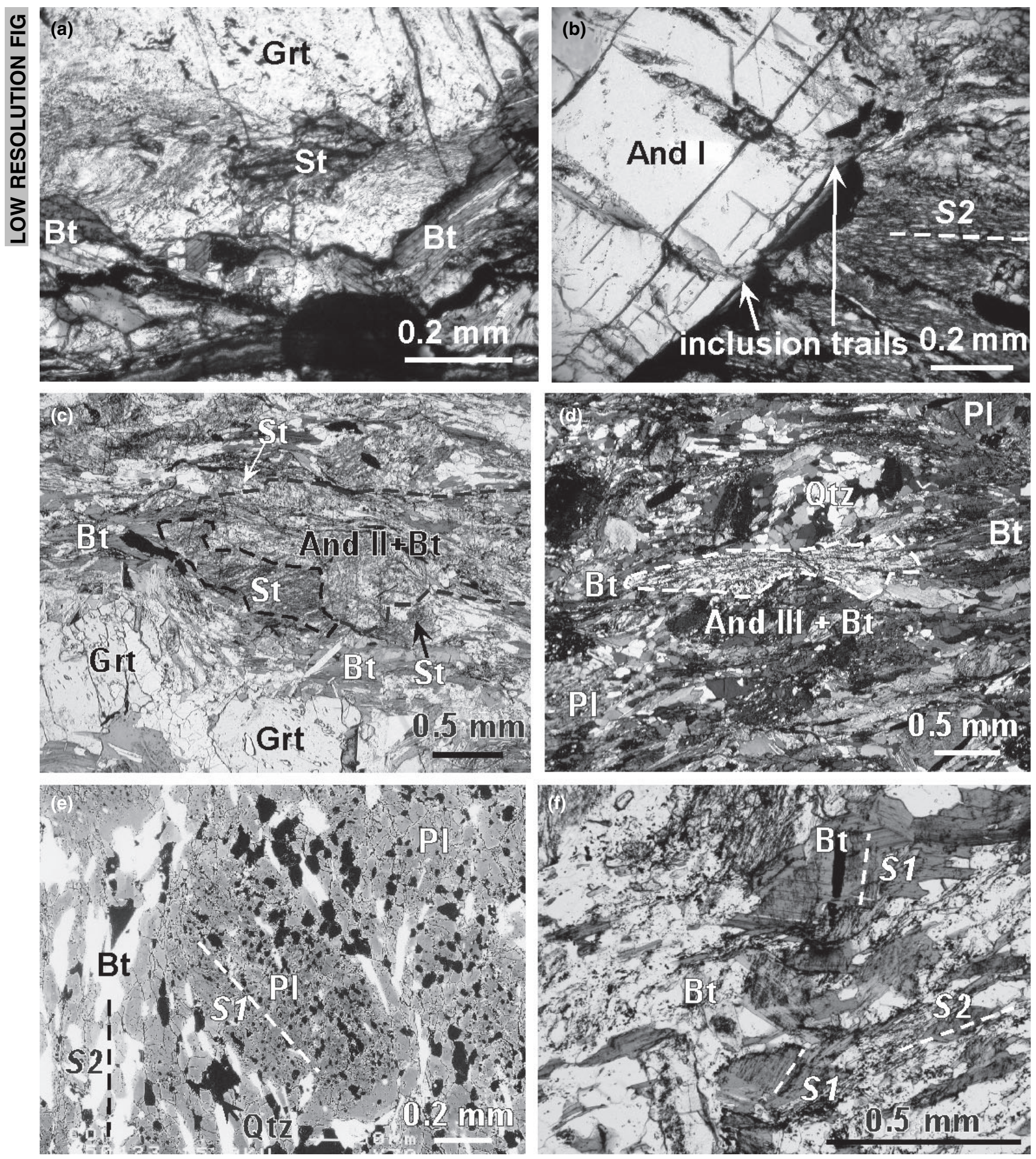

Fig. 10. Photomicrographs of a Cuobu metapelite (sample MSA5a). (a) A staurolite inclusion within a garnet rim. Open nicol. (b) A type I andalusite porphyroblast with a graphite defined rim inclusion trail that is continuous with the matrix S2. Open nicol. (c) A staurolite porphyroblast replaced by andalusite II + biotite. Open nicol. (d) Andalusite III selectively overgrowing a mica-rich layer that defines S2. Crossed nicols. (e) BSE image of plagioclase porphyroblast and smaller matrix plagioclase grains. Note that the core of the plagioclase is dark grey and the rim is light grey, showing rim-ward increase in anorthite content. (f) Biotite grains with S1 inclusions at the core and inclusion-poor rim. Open nicol. 


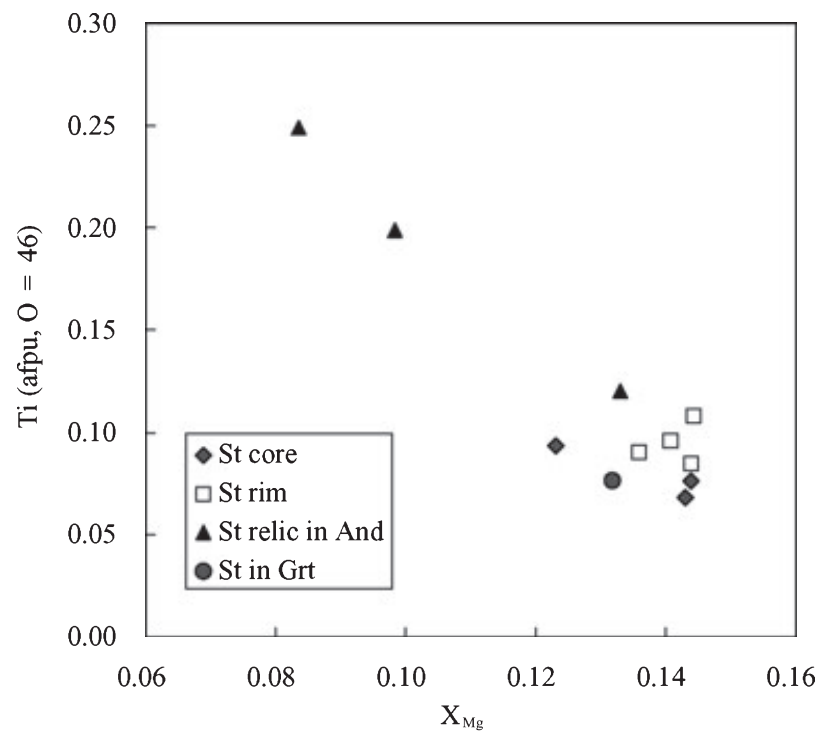

Fig. 11. A $X_{\mathrm{Mg}}$-Ti plot of staurolite composition from the Cuobu metapelite (sample MSA5a).

fore, that the plagioclase core formed during a nondeformational period between D1 and D2. Plagioclase shows an increase in anorthite content from An32-35 in the core to An38-40 in the rim. Ilmenite locally includes chlorite and quartz.

\section{PRESSURE-TEMPERATURE HISTORY OF THE MALASHAN METAPELITES}

Petrographic recognition of episodic emplacement of three granites

The timing of mineral growth relative to the two deformational stages, D1 and D2, as constrained from the microstructural observations is summarized in Fig. 15. Because of the development of textural sector zoning in garnet cores and retrograde replacement of garnet rims, it is difficult to constrain the relative timing of garnet growth. The growth of garnet before the non-deformational period between D1 and D2 is obvious from the observation of MSW28 for the Malashan metapelite. However, the presence of staurolite inclusions in the garnet rim and similarity of its composition with that of staurolite core strongly support post-D1 to pre-D2 growth of the garnet rim in the Cuobu metapelite.

In spite of the difficulty in strictly constraining the growth timing of garnet, three distinct metamorphic stages can be defined in terms of mineral paragenesis, using staurolite and andalusite as index minerals: (I) staurolite-absent, (II) staurolite-present and andalusiteabsent and (III) andalusite-present stages (Fig. 15).

The fact that andalusite is observed only in the areas adjacent to the Paiku and Cuobu granites and not in the vicinity of the Malashan granite (Fig. 1b), in spite of the similarity of the whole-rock compositions of metapelites around the three granites (Fig. 7), indicates that the andalusite formation can be attributed to the localized contact metamorphism caused by intrusion of the Paiku and Cuobu granites (Table 3). The andalusite-forming stage in the Cuobu and Paiku metapelites corresponds to the chlorite forming state in the Malashan metapelites (Figs 9i \& 15), indicating that a drop in temperature occurred at this stage in the Malashan metapelites (Fig. 13).

It can further be deduced that metamorphism associated with the earlier emplacement of the Malashan granite would be characterized by the formation of the staurolite whose growth occurred post-D1 to syn-D2 (Fig. 15). The cores of the biotite (Fig. 10f) and plagioclase porphyroblasts (Fig. 10e) also grew mainly at this stage.

\section{Pressure-temperature estimation of the non-deformational stage between D1 and D2}

Our textural and petrographic observations suggest that in the Cuobu metapelites the cores of plagioclase and biotite, the rim of garnet, and muscovite coexisted during a non-deformational stage between D1 and D2. Muscovite does not show evidence for twostage growth and is compositionally homogeneous. In the Malashan metapelites, garnet grew pre- to syn-D1 and these four metamorphic minerals did not coexist (Fig. 15). In the Paiku metapelites, these four metamorphic minerals appear to have coexisted, but the evidence is equivocal. Therefore, only the plagioclasebiotite-garnet-muscovite (PBGM) geothermobarometers (Ghent \& Stout, 1981) were applied to the $\mathrm{Cu}$ obu metapelites to estimate the $P-T$ conditions of the non-deformational stage between D1 and D2 and adjacent to the Malashan granite (Fig. 15). Utilizing garnet rims, plagioclase cores, matrix biotite cores and matrix muscovite compositions in sample MSA5a yields a $P-T$ estimate of $4.8 \pm 0.8 \mathrm{kbar}$ at $550 \pm 50{ }^{\circ} \mathrm{C}$.

\section{Pressure-temperature estimation of syn- to post-D2 stage}

The $P-T$ conditions of emplacement of the Paiku and Cuobu granites are constrained utilizing reaction textures and mineral assemblages (Fig. 13). In the skarn from the Malashan dome, wollastonite is not found and grossular-rich garnet + calcite + quartz are stable. Therefore, the metamorphic conditions of the whole Malashan dome did not exceed the $P-T$ conditions for the reaction (Fig. 13a)

$$
\mathrm{Cal}+\mathrm{Qtz}=\mathrm{Wo}+\mathrm{CO}_{2}
$$

and

$$
\text { Grossular }+ \text { Qtz }=\mathrm{An}+\mathrm{Wo} \text {. }
$$

The $P-T$ condition for reaction (1), however, is largely controlled by $X_{\mathrm{CO}_{2}}$ of the coexisting fluid and thus this 

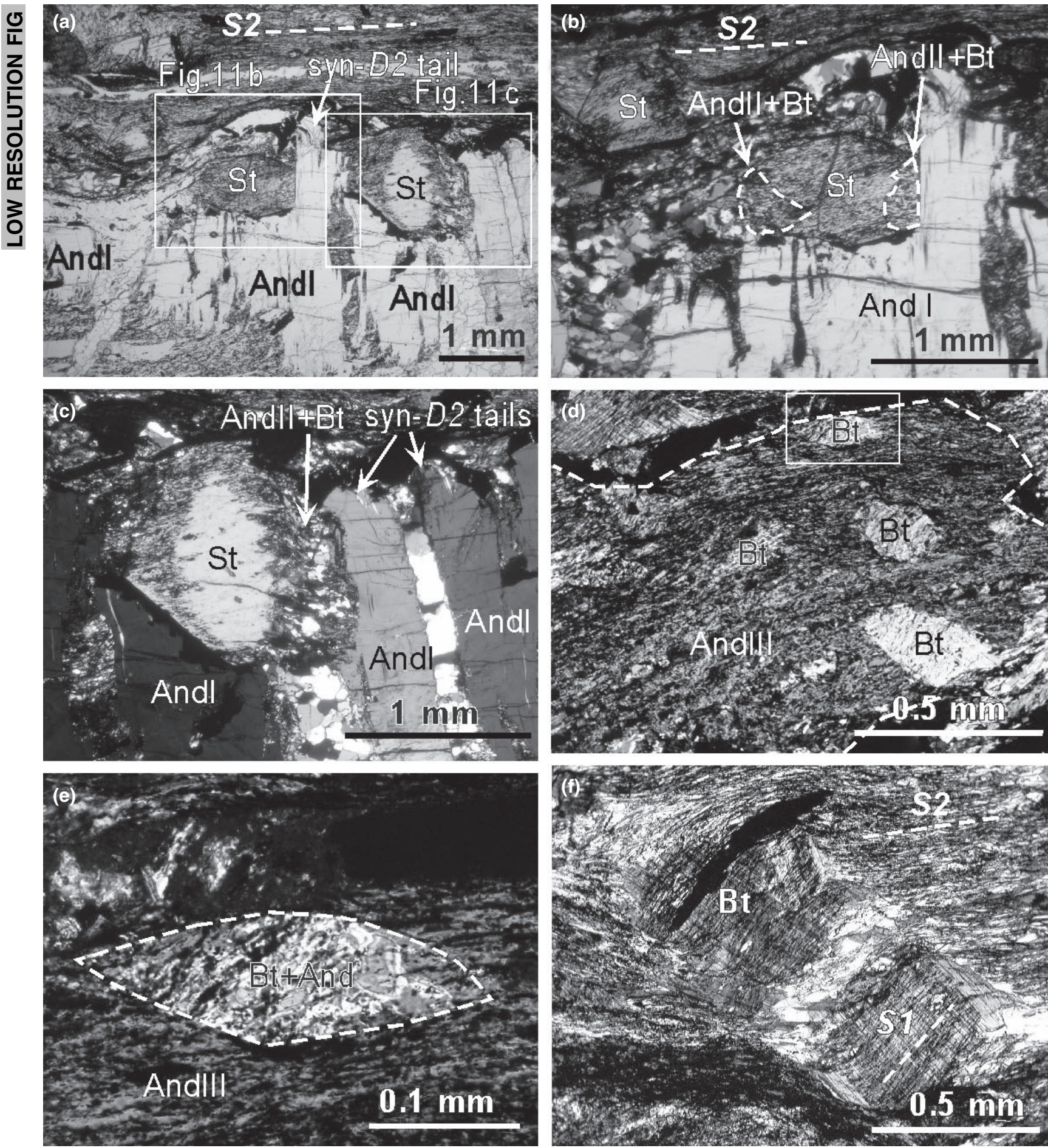

Fig. 12. Photomicrographs of the Paiku metapelite (sample MSL02-20). (a) Porphyroblastic andalusite I and adjacent staurolite partly replaced by the andalusite III + biotite intergrowth. The rim of andalusite I exposes a syn-D2 tail (arrow). Open nicol. (b) Enlargement of staurolite in (a). Staurolite rim is replaced by andalusite II + biotite intergrowth. The andalusite II on the right-hand side of the staurolite shows simultaneous extinction with andalusite I. Crossed nicols. (c) Enlargement of staurolite in (a). Andalusite II + biotite define the pull-apart structure developed between staurolite and andalusite I, suggesting syn-D2 growth of andalusite II and the rim of andalusite I. Syn-D2 tails are also shown by arrows. Crossed nicols. (d) Andalusite III replacing micaceous layers. 'Patchy' biotite crystals, possibly after staurolite, are included in andalusite. Crossed nicols. (e) Enlargement of boxed part of (d) Andalusite + biotite intergrowth is included in andalusite III. Note that andalusite in the intergrowth and surrounding andalusite III show simultaneous extinction, suggesting that they are the same single crystal. Crossed nicols. (f) Biotite with S1 in the core and inclusion-poor rim. The grain shape of biotite suggests that these grains grew during D2. Open nicol. 
Fig. 13. $P-T$ conditions for the metapelites from the Malashan area based upon microstructural and geothermobarometric studies. (a) $P-T$ conditions for reactions (2) and (3). Reaction (1) is largely controlled by $X_{\mathrm{CO}_{2}}$ of coexisting fluid and thus not shown in this figure. Reaction (2) is from Newton (1966) and Boettcher (1970), reaction (3) is from Pattison \& Vogl (2005). (b) The psudosection is from Waters \& Lovegrove (2002). The star represents the $P-T$ estimate for the nondeformational stage preserved in Cuobu metapelites using the PBGM geothermobarometry. The black dashed line shows the aluminosilicate stability fields of Pattison (1992) and the grey dashed line is that of Holdaway (1971).

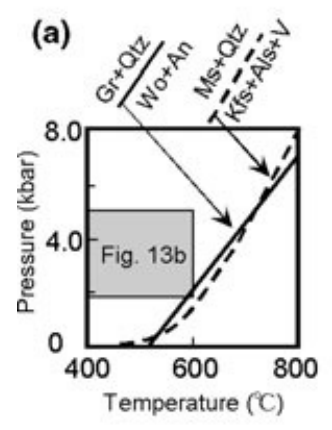

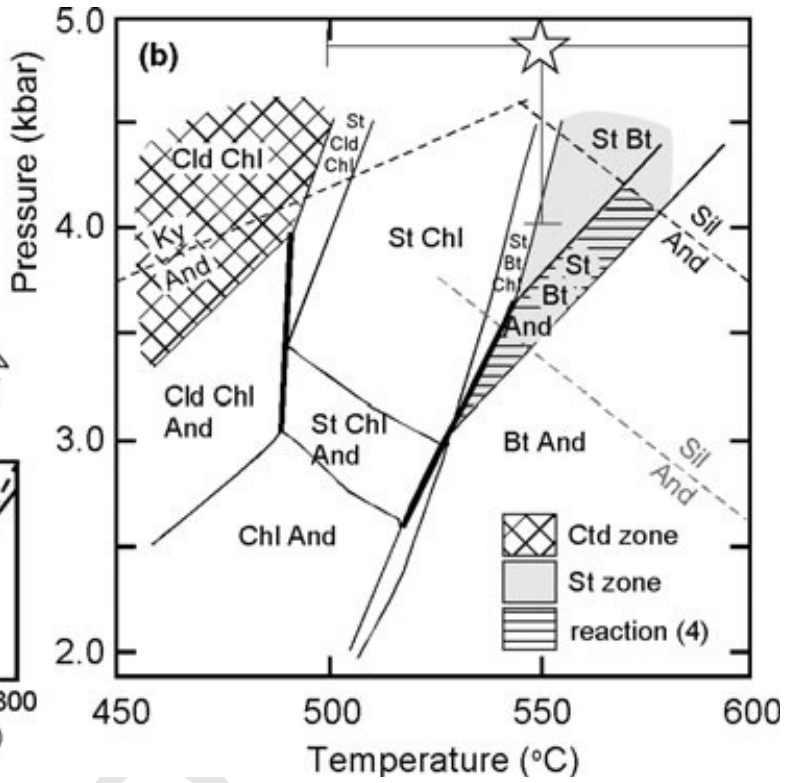

reaction is not suitable for a $P-T$ estimate of metamorphism unless $X_{\mathrm{CO}_{2}}$ cam be constrained separately.

In the Cuobu and Paiku metapelites, syn-D2 andalusite porphyroblasts (andalusite I) are found. Because the muscovite + quartz assemblage is stable and $\mathrm{K}$-feldspar and sillimanite are absent in those metapelites, they did not exceed the $P-T$ conditions for the reaction (Fig. 13a)

$$
\mathrm{Ms}+\mathrm{Qtz}=\text { And } / \mathrm{Sil}+\mathrm{Kfs}+\mathrm{H}_{2} \mathrm{O} .
$$

Because staurolite is partly replaced by andalusite II + biotite, and such andalusite crystals do not commonly include muscovite in spite of its abundance in the matrix, the continuous reaction

$$
\mathrm{St}+\mathrm{Ms}+\mathrm{Qtz}=\mathrm{And}+\mathrm{Bt}+\mathrm{H}_{2} \mathrm{O}
$$

explains formation of andalusite II. The observation that relic staurolite found in andalusite II represents lower $X_{\mathrm{Mg}}$ value than the matrix staurolite is consistent with an increase in temperature associated with reaction (4). Reaction (4) is post-D2 in the Cuobu metapelites because andalusite II + biotite are not deformed by D2, but is syn-D2 in Paiku metapelites because andalusite II + biotite define syn-D2 pull-apart structures (Fig. 12c). The formation reactions for andalusites I and III are the same as that for andalusite II, because the rim of andalusite I grew almost simultaneously with andalusite II, and because andalusite III locally includes patchy biotite crystals probably after staurolite.

The $P-T$ conditions for reaction (4) are approximately $3.1-3.4 \mathrm{kbar}$ and $530-540{ }^{\circ} \mathrm{C}$, based on the $P-T$ pseudosection in the KFMASH system for the Bushveld Complex aureole (Waters \& Lovegrove, 2002; Fig. 13b) which has a similar whole-rock composition $\left(A=0.40, X_{\mathrm{Mg}}=0.26\right)$ to the Malashan region $\left(A=0.46-0.53, X_{\mathrm{Mg}}=0.24-0.27\right)$, where $A=$ $\left(\mathrm{Al}_{2} \mathrm{O}_{3}-3 \mathrm{~K}_{2} \mathrm{O}\right) /\left(\mathrm{Al}_{2} \mathrm{O}_{3}-3 \mathrm{~K}_{2} \mathrm{O}+\mathrm{FeO}+\mathrm{MgO}\right)$. The pseudosection of Waters \& Lovegrove (2002) also predicts, when extrapolated to a higher-pressure $P-T$ field, the mineral assemblage staurolite + biotite + muscovite + plagioclase + quartz at $4.8 \mathrm{kbar}$ and $560-610{ }^{\circ} \mathrm{C}$. This mineral assemblage is observed in the Cuobu metapelite of non-deformational stage, although garnet is also present in the Cuobu metapelite. Garnet cannot be appropriately modelled by the KFMASH system, but it can be stabilized by the addition of $\mathrm{Mn}$ to the system at the $P-T$ conditions mentioned above. In addition, the stability field of staurolite + biotite can be enlarged by taking into account the effect of $\mathrm{Zn}$ and $\mathrm{Cr}$ contained in natural staurolite. Therefore, the mineral assemblage predicted in the pseudosection of Waters \& Lovegrove (2002) and the result of $P-T$ estimates of non-deformational stage estimated by PBGM geothermobarometers $\left(4.8 \pm 0.8 \mathrm{kbar}\right.$ at $\left.550 \pm 50^{\circ} \mathrm{C}\right)$ do not conflict with each other if the effects of minor components are taken into account. Combining the two $P-T$ estimates, $4.8 \pm 0.8 \mathrm{kbar}$ at $550 \pm 50{ }^{\circ} \mathrm{C}$ for the non-deformational stage between D1 and D2 and 3.1-3.4 kbar at $530-540{ }^{\circ} \mathrm{C}$ for the syn- to post-D2 stage, defines a nearly isothermal decompression path for the Cuobu metapelites if the aluminosilicate diagram of Holdaway (1971) is used (Fig. 13). A recent study using primary melt inclusions in andalusite (Cesare et al., 2003) suggests a higher aluminosilicate $P-T$ triple point such as that suggested by Pattison (1992). If the triple point of Pattison (1992) is used, then the $P-T$ estimates are $3.1-4.1 \mathrm{kbar}$ at $530-575{ }^{\circ} \mathrm{C}$ for the postD2 stage. In this case, a pressure difference between the two stages may not exist and andalusite formed as a consequence of isobaric heating. 


\section{DISCUSSION}

\section{Origin of Tertiary granites in the Malashan area}

Combining our geochronological data on the Paiku granite with the geochronological results of Aoya et al. (2005, 2006) shows that all three granites in the Malashan dome are early Miocene intrusions with slightly different emplacement and cooling ages. These results support the interpretation of Watts et al. (2005) that there is a systematic westward increase in the 'Tertiary granite' component within the NHGD.

Aoya et al. (2006) pointed out the similarity in whole-rock composition of the Malashan and Cuobu granites with other North Himalayan granites, including Kangmar dome, and the similarity of Paiku granite with the High Himalayan leucogranites (HHL). However, they treat the Cenozoic granites and the Kangmar gneiss as 'North Himalayan granites'. Although it is possible that future zircon-rim SHRIMP geochronology of the Kangmar gneiss may yield younger ages, based on the results of Schärer et al. (1986) and Lee et al. (2000), the Kangmar gneiss is considered to be Cambrian by most workers. In this study, we follow the generally accepted division to investigate the affinities of the three granites in the Malashan area.

In a crustal environment, accessory minerals are an important sink for most trace elements. The sluggish nature of their dissolution in the melt together with fast extraction of the melt from the protolith may result in the formation of 'disequilibrium melt' (Watt \& 3Harley, 1993). However, $\mathrm{Rb}, \mathrm{Sr}$ and $\mathrm{Ba}$ reside predominantly in major minerals such as mica and feldspar in the granitic system and thus are more likely to attain equilibrium. Hence, they are appropriate for modelling melt compositions produced by the micabearing melt reactions (Harris \& Inger, 1992). Figure 14 is the $\mathrm{Ba}-\mathrm{Rb} / \mathrm{Sr}$ plot of granites and metapelites from the Malashan area, other NHGD, HHL and High Himalayan Crystalline Sequence (HHCS). Metapelites in the Malashan dome plot at the highest $\mathrm{Ba}$ and lowest $\mathrm{Rb} / \mathrm{Sr}$ edge of the trend defined by all of the data plotted, and plot similar to the field defined by the HHCS. Under the assumption that the protolith of the Malashan dome granites resembles the Malashan metapelites or the HHCS, the magma-protolith relation on the $\mathrm{Ba}-\mathrm{Rb} / \mathrm{Sr}$ plot (Fig. 14) is useful in constraining what kind of mica-related melting reaction is plausible for the Malashan dome granites. The Harker diagrams (Aoya et al., 2006) and $\mathrm{Ba}-\mathrm{Rb} / \mathrm{Sr}$ plot show that the Paiku granite resembles the Cenozoic Mabja granite (Zhang et al., 2004), and both of them plot within the compositional field of the HHL. The Malashan and Cuobu granites both show similar chemical composition with other Cenozoic North Himalayan granites (e.g. Debon et al., 1986). Isotopic studies are compatible with the Tertiary granites of the NHGD being generated by mica dehydration reactions

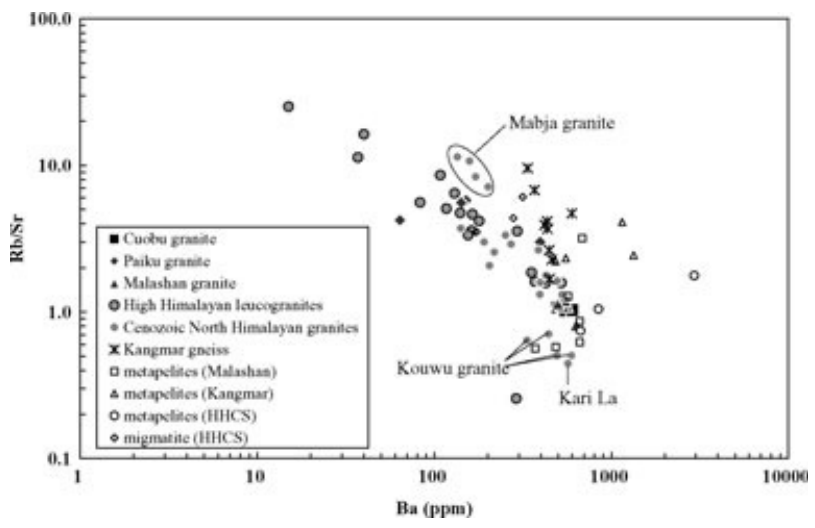

Fig. 14. A Ba- $\mathrm{Rb} / \mathrm{Sr}$ plot of granites and metapelites from the Malashan area, other NHGD, HHL and HHCS. Whole-rock composition data of granites of the Malashan area are from Aoya et al. (2006). Other data sources of granites and metapelites composition are Debon et al. (1986), Inger \& Harris (1993) and Zhang et al. (2004).

from a source identical to that of the HHL (Zhang et al., 2004). Although isotopic data are not available from the Malashan area, the similarity of major and trace element compositions with isotopically wellcharacterized Tertiary granites implies that the Malashan granite also formed through mica dehydration reactions. It is significant that in the $\mathrm{Ba}-\mathrm{Rb} / \mathrm{Sr}$ plot, the Paiku granite plots on the negative correlation trend defined by the HHL, suggesting that vapour-absent muscovite melting (Inger \& Harris, 1993; Zhang et al., 2004) played a key role in producing the Paiku granite. The Malashan and Cuobu granites plot on the highest Ba part of the same compositional trend, where the metapelites from the High Himalayan Crystalline Series (HHCS) and the Malashan area are plotted (Fig. 14). Therefore, it is difficult to constrain the

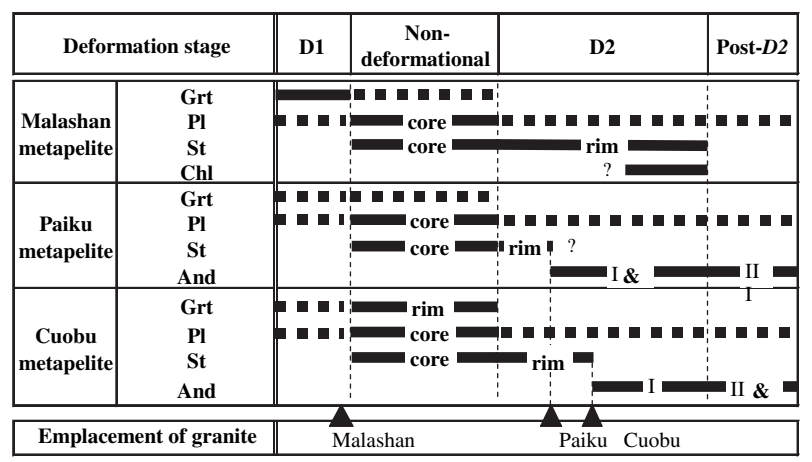

Fig. 15. Timing relationship between two deformational stages (D1 and D2) observed in the Malashan area and mineral growth in the metapelites around three granites. Black lines represent period of mineral growth. Broken lines represent possible growth of minerals that are not confirmed by textural observation.

Timing of granite intrusion is based on Aoya et al. (2006). Difference in growth timing of andalusite during D2 between Paiku and Cuobu metapelites is deduced from the intrusion sequence of Paiku and Cuobu granites (Aoya et al., 2005). 
modes of mica-related melting reaction of the Malashan and Cuobu granites from the $\mathrm{Ba}-\mathrm{Rb} / \mathrm{Sr}$ plot.

\section{Age constraints on shallow extensional tectonics within the hangingwall to the STDS}

The Tethyan Himalayan region between the STDS and the Yarlang Tsangpo suture zone is occupied by a series of deformed and partly metamorphosed sediments ranging in age from Ordovician to Eocene from south to north (Burchfiel et al., 1992). Despite the strong deformation, the stratigraphic level is a useful proxy for structural level (Aoya et al., 2006). This is confirmed by the association of the Kangmar Dome with Palaeozoic metasediments and kyanite-stable metamorphism in contrast to the association of the Malashan Dome with Jurassic age metasediments and andalusite-stable metamorphism. The NHGD are located $50-60 \mathrm{~km}$ north of the STDS. Estimates of metamorphic pressures in these regions suggest that synmetamorphic D2 deformation took place at depths of $30-40 \mathrm{~km}$ (Lee et al., 2000, 2004, 2006; Quigley et al., 2006). Directly linking D2 in these regions with the STDS implies a dip of around $30^{\circ}$; rather shallow for a normal fault. To extrapolate this link into the much shallower level D2 of the Malashan Dome requires not only a very gentle north dip but also a first order change in structural level along strike. Lateral changes in structural level of major continental detachments of $1 \mathrm{~km}$ scale have been reported (Lee et al., 1999), but changes in excess of $10 \mathrm{~km}$ seem unlikely. We suggest that D2 deformation which affects the Malashan metasediments is related to but occurred at a distinct structural level to the D2 deformation documented in other domes. This is important in discussing the extent to which the Tethyan Himalayan region can be treated as a rigid lid to a mobile mid to lower crust (Beaumont et al., 2004; Aoya et al., 2005).

The metamorphism documented in this contribution is important to constrain $P-T$ conditions during the phase of $\mathrm{D} 2$ ductile extension. This information can in turn be used in conjunction with geochronology to constrain the timing of extension. The pressure estimates for the non-deformational and syn- to post-D2 stages are $4.8 \pm 0.8 \mathrm{kbar}(=17.8 \pm 3.0 \mathrm{~km})$ and $3.1-4.1 \mathrm{kbar}(=11.5-15.2 \mathrm{~km})$ respectively (Fig. 13). The pressure estimate for the syn- to post D2 metamorphism indicates that D2 deformation occurred at middle to upper crustal depths. This estimate for the depth of D2 deformation is relatively shallow compared to the other domes (cf. Chen et al., 1990; Lee et al., 2000, 2004, 2006; Quigley et al., 2006). The D2 deformation initiated after intrusion of the Malashan granite $(17.8 \pm 1.1 \mathrm{Ma}$; Aoya et al., 2005) and appears to have ceased before formation of andalusite II and III in the Cuobu metapelites (Figs 10c,d \& 15). As formation of the andalusite occurred well above the ${ }^{40} \mathrm{Ar}-{ }^{39} \mathrm{Ar}$ closure temperature for muscovite (Fig. 13), the muscovite ${ }^{40} \mathrm{Ar}-{ }^{39} \mathrm{Ar}$ cooling age of $15.68 \pm$
0.06 Ma from the Cuobu granite (Aoya et al., 2005) provides younger limit for $\mathrm{D} 2$ deformation. Therefore, the duration of D2 extensional deformation in the Malashan area is $\sim 2 \mathrm{Myr}$, beginning at $c .17 .8 \mathrm{Ma}$ and ending at $c .15 .7 \mathrm{Ma}$. Heating of the sediments by the intrusion of the Malashan granite during the last stage of D1 possibly triggered the onset of D2 in the Malashan area (Aoya et al., 2005). The fact that metasediments surrounding the Malashan granite are mainly calcareous and contain abundant calcite could have been an important factor that facilitated the intense ductile deformation during D2 at around $500-600{ }^{\circ} \mathrm{C}$ in the Malashan dome. The onset of D2 may have triggered the intrusion of the Paiku and Cuobu granites (Aoya et al., 2005), mainly driven by extensional thinning of the overlying crust and by the buoyancy of the granites.

\section{Effect of fluid activity at the granite intrusion front}

In addition to the thermal effect of the granite intrusions, the presence of deformed calcite + quartz dykes that were formed during D1 until the end of D2 (Fig. 5d; Aoya et al., 2006) suggests that intense dyking caused by the activity of fluid at the granite intrusion front may also have played a role in weakening the upper crust. The presence of interstitial water in the calcite rocks is not significant at higher temperatures (Rutter, 1974). However, when significant pore pressures are developed inside the rock under undrained conditions, the rock becomes weak under shear stress and can fail by brittle faulting, even at elevated temperature (Rutter \& Brodie, 1995). Common and widespread distribution of calcareous metasedimentary rocks accompanied by abundant calcite + quartz veins around the Malashan granite suggests that a fluid phase was available around the granite body. These veins cut $\mathrm{S} 1$ and are boudinaged or folded by D2 depending on the orientation of the veins (Fig. 5d,e). Hence, vein formation began syn-D1 deformation (Fig. 9c) and continued until the final stage of D2 deformation (Fig. 6a; Aoya et al., 2006). This syn-D1 to final stage of D2 fluid activity is nearly synchronous with that of the granite intrusions (Table 3). The fluid also permeated into grain boundaries of calcareous metasedimentary rocks as suggested by the replacement of former porphyroblasts, whose identity is unknown, by plagioclase + quartz \pm calcite aggregates. Availability of such fluids during contact metamorphism may have weakened the crust surrounding the granitic body through formation of dykes that provided the vertical pathways of granitic magmas, as well as pathways for the vertical fluid flow that could transport the heat effectively, resulting in thermal weakening of the overlying crust. The potential sources of the fluids were (i) the cooling granite magma and (ii) dehydration of pelites and decarbonation of calcareous sediments during the prograde contact metamorphism. 
Judging from the fact that the unknown porphyroblasts, replaced by plagioclase + quartz \pm calcite, are found at least $5 \mathrm{~km}$ away from the Malashan pluton, and taking into account the average $\operatorname{dip}\left(\sim 30^{\circ}\right)$ of the D2 foliation that is parallel to the granite/metasediment contact, the thickness of the metasediments that are affected by this weakening process may exceed $3 \mathrm{~km}$ (equivalent of about $0.8 \mathrm{kbar}$ ).

\section{ACKNOWLEDGEMENTS}

We are grateful to T. Tsujimori, C. Gouzu and T. Itaya for WDS analyses at OUS, to K. Miyazaki, M. Fukuyama and N. Shigematsu for discussion, T. Argles and W. McClelland for critical reviews of the previous version of the manuscript, and to D. Robinson for editorial assistance. This study was financially supported in part by the Grant-in-Aid for Scientific Research (B) (13573011) from JSPS to S. Wallis, a grant from Central Washington University to J. Lee and a grant from Kyoto University to T. Kawakami.

\section{REFERENCES}

Alsdorf, D. \& Nelson, D. 1999. Tibetan satellite magnetic low; evidence for widespread melt in the Tibetan crust? Geology, 27, 943-946.

Alsdorf, D., Brown, L., Nelson, K. D., Makovsky, Y., Klemperer, S. \& Zhao, W. 1998, Crustal deformation of the Lhasa terrane, Tibet plateau from Project INDEPTH deep seismic reflection profiles. Tectonics, 17, 501-519.

Aoya, M., Wallis, S., Terada, K. et al. 2005. North-South extension in the Tibetan crust triggered by granite emplacement. Geology, 33, 853-856.

Aoya, M., Wallis, S. R., Kawakami, T., Lee, J., Wang, Y. \& Maeda, H. 2006. The Malashan gneiss dome in south Tibet: comparative study with the Kangmar dome with special reference to kinematics of deformation and origin of associated granites. In: Channel Flow, Ductile Extrusion and Exhumation of Lower-mid Crust in Continental Collision Zones, Special Publication 268 (eds Law, R.D., Searle, M.P. \& Godin, L.), pp. 471-495. Geological Society, London.

Beaumont, C., Jamieson, R. A., Nguyen, M. H. \& Lee, B. 2001. Himalayan tectonics explained by extrusion of a low-viscosity crustal channel coupled to focused surface denudation. Nature, 414, 738-742.

Beaumont, C., Jamieson, R. A., Nguyen, M. H. \& Medvedev, S. 2004. Crustal channel flows: 1 . Numerical models with applications to the tectonics of the Himalayan-Tibetan orogen. Journal of Geophysical Research, 109, B06406.

Boettcher, A. L. 1970. The system $\mathrm{CaO}-\mathrm{Al}_{2} \mathrm{O}_{3}-\mathrm{SiO}_{2}-\mathrm{H}_{2} \mathrm{O}$ at high pressures and temperatures. Journal of Petrology, 11, 337-379.

Burchfiel, B. C., Chen, A., Hodges, K. V. et al. 1992. The South Tibetan detachment system, Himalayan orogen: extension contemporaneous with and parallel to shortening in a collisional mountain belt. Geological Society of America Special Paper, 269, 41.

Burg, J. P., Guiraud, M., Chen, G. M. \& Li, G. C. 1984, Himalayan metamorphism and deformations in the North Himalayan Belt (southern Tibet, China). Earth and Planetary Science Letters, 69, 391-400.

Cesare, B., Marchesi, C., Hermann, J. \& Gomez-Pugnaire, M. T. 2003. Primary melt inclusions in andalusite from anatectic graphitic metapelites: implications for the position of the Al2SiO5 triple point. Geology, 31, 573-576.
Chen, Z., Liu, Y., Hodges, K. V., Burchfiel, B. C., Royden, L. H. \& Deng, C. 1990. The Kangmar dome: a metamorphic core complex in southern Xizang (Tibet). Science, 250, 1552-1556.

Chen, L., Booker, J. R., Jones, A. G. et al. 1996. Electorically conductive crust in southern Tibet from INDEPTH magnetotelluric surveying. Science, 274, 1694-1696.

Debon, F., Le Fort, P., Sheppard, S. \& Sonet, J. 1986. The four plutonic belts of the Transhimalaya-Himalaya: a chemical, mineralogical, isotopic, and chronological synthesis along a Tibet-Nepal Section. Journal of Petrology, 27, 219-250.

Droop, G. T. R., 1987. A general equation for estimating $\mathrm{Fe}^{3+}$ concentrations in ferromagnesian silicates and oxides from microprobe analyses, using stoichiometric criteria. Mineralogical Magazine, 51, 431-435.

Edwards, M. A. \& Harrison, T. M. 1997. When did the roof collapse? Late Miocene N-S extension in the high Himalaya revealed by $\mathrm{Th}-\mathrm{Pb}$ dating of the Khula Kangri granite. Geology, 25, 543-546.

Ghent, E. D. \& Stout, M. Z. 1981. Geobarometry and geothermometry of plagioclase-biotite-garnet-muscovite assemblages. Contributions to Mineralogy and Petrology, 76, 92-97.

Goto, A. \& Tatsumi, Y. 1994. Quantitative analysis of rock samples by an X-ray fluorescence spectrometer (I). The Rigaku Journal, 11, 40-59.

Harris, N. \& Inger, S. 1992. Trace element modeling of pelitederived granites. Contributions to Mineralogy and Petrology, 110, 46-56.

Harrison, T. M., Grove, M., McKeegan, K. D., Coath, C. D., Lovera, O. \& Le Fort, P. 1999. Origin and episodic emplacement of the Manaslu Intrusive Complex, Central Himalaya. Journal of Petrology, 40, 3-19.

Hauck, M. L., Nelson, K. D., Brown, L. D., Zhao, W. \& Ross, A. R. 1998. Crustal structure of the Himalayan orogen at $\sim 90^{\circ}$ east longitude from Project INDEPTH deep reflection profiles. Tectonics, $\mathbf{1 7}, 481-500$.

Hodges, K. V., 2000. Tectonics of the Himalaya and southern Tibet from two perspectives. GSA Bulletin, 112, 324-350.

Hodges, K. V., Parrish, R. R., Hoish, T. B. et al. 1992. Simultaneous Miocene extension and shortening in the Himalaya orogen. Science, 258, 1466-1469.

Hodges, K. V., Parrish, R. R. \& Searle, M. P. 1996. Tectonic evolution of the central Annapurna Range, Nepalese Himalayas. Tectonics, 15, 1264-1291.

Holdaway, M. J. 1971. Stability of andalusite and the aluminum silicate phase diagram. American Journal of Science, 271, 97131.

Inger, S. \& Harris, N. 1993. Geochemical Constraints on Leucogranite Magmatism in the Langtang Valley, Nepal Himalaya. Journal of Petrology, 34, 345-368.

Jamieson, R. A., Beaumont, C., Medvedev, S. \& Nguyen, M. H. 2004. Crustal channel flows: 2. Numerical models with implications for metamorphism in the Himalayan-Tibetan orogen. Journal of Geophysical Research, 109, B06407.

Kretz, R., 1983. Symbols for rock forming minerals. American Mineralogist, 68, 277-279.

Lee J. \& Whitehouse, M. J. 2007, Onset of mid-crustal extensional flow in southern Tibet: evidence from $\mathrm{U} / \mathrm{Pb}$ zircon ages. Geology, 35, 45-48.

Lee, J., Miller, E. L., Gans, P. B. \& Huggins, C. C. 1999. Geologic Map of the Mount Moriah Quadrangle. Field Studies Map 19, scale 1:24,000. Nevada Bureau of Mines and Geology, Nevada, 12 pp.

Lee, J., Hacker, B. R., Dinklage, W. S. et al., 2000. Evolution of the Kangmar Dome, southern Tibet: structural, petrologic, and thermochronologic constraints. Tectonics, 19, 872895.

Lee, J., Hacker, B. \& Wang, Y. 2004. Evolution of North Himalayan Gneiss Domes: structural and metamorphic studies in Mabja Dome, southern Tibet. Journal of Structural Geology, 26, 2297-2316. 
Lee, J., McClelland, W., Wang, Y., Blythe, A. \& McWilliams, M. 2006. In: Oligocene-Miocene Middle Crustal Flow in Southern Tibet: Geochronology of Mabja Dome. Channel Flow, Ductile Extrusion and Exhumation in Continental Collision Zones, Special Publication 268 (eds Law, R.O., Searle, M.P. \&

5 Godin L.), pp. 445-469. Geological Society, London.

London, D. \& Manning, D. A. C. 1995. Chemical variation and significance of tourmaline from Southwest England. Economic Geology, 90, 495-519.

Makovsky, Y., Klemperer, S. L., Huang, L. \& Lu, D. 1996. Structural elements of the southern Tethyan Himalaya crust from wide-angle seismic data. Tectonics, 15, 997-1005.

McDougall, I. \& Harrison, T. M. 1999. Geochronology and Thermochronology by the ${ }^{40} \mathrm{Ar}-{ }^{39} \mathrm{Ar}$ Method. Oxford University Press, ????????. 269 pp.

Nelson, K.D., Zhao W., Brown, L. D. et al. 1996. Partially molten middle crust beneath southern Tibet: synthesis of project INDEPTH results. Science, 274, 1684-1688.

Newton, R. C. 1966. Some calc-silicate equilibrium reactions. American Journal of Science, 264, 204-222.

Pattison, D. R. M. 1992. Stability of andalusite and sillimanite and the $\mathrm{Al}_{2} \mathrm{SiO}_{5}$ triple point: constraints from the Ballachulish aureole, Scotland. Journal of Geology, 100, 423-446.

Pattison, D. R. M. \& Vogl, J. J. 2005. Contrasting sequences of metapelitic mineral-assemblages in the aureole of the tilted Nelson Batholith, British Columbia: implications for phase equilibria and pressure determination in andalusitesillimanite-type settings. The Canadian Mineralogist, 43, 5188.

Pitra, P. \& Guiraud, M. 1996. Probable anticlockwise $P-T$ evolution in extending crust: Hlinsko region, Bohemian Massif. Journal of metamorphic Geology, 14, 49-60.

Quigley, M., Liangjun Y., Xiaohan, L., Wilson, C. J. L., Sandiford, M. \& Phillips, D. 2006. ${ }^{40} \mathrm{Ar} /{ }^{39} \mathrm{Ar}$ thermochronology of the Kampa Dome, southern Tibet: Implications for tectonic evolution of the North Himalayan gneiss domes. Tectonophysics, 421, 269-297.

Rutter, E. H. 1974. The influence of temperature, strain rate and interstitial water in the experimental deformation of calcite rocks. Tectonophysics, 22, 311-334.
Rutter, E. H. \& Brodie, K. H. 1995. Mechanistic interactions between deformation and metamorphism. Geological Journal, 30, 227-240.

Sano, Y., Hidaka, H., Terada, K., Shimizu, H. \& Suzuki, M. 2000. Ion microprobe U-Pb zircon geochronology of the Hida gneiss: finding of the oldest minerals in Japan. Geochemical Journal, 34, 135-153.

Schärer, U., Xu, R. \& Allegre, C. 1986. U-(Th)-Pb systematics and ages of Himalayan leucogranites, south Tibet. Earth and Planetary Science Letters, 77, 35-48.

Searle, M. P. 1999. Extensional and compressional faults in the Evelest-Lhotse massif, Khumbu Himalaya, Nepal. Journal of the Geological Society, London, 156, 227-240.

Searle, M. P., Parrish, R. R., Hodges, K. V., Hurford, A., Ayres, M. W. \& Whitehouse, M. J. 1997. Shisha Pangma leucogranite, south Tibetan Himalaya: field relations, geochemistry, age, origin, and emplacement. Journal of Geology, 105, 295317.

Simpson, R. L., Parrish, R. R., Searle, M. P. \& Waters, D. J. 2000. Two episodes of monazite crystallization during metamorphism and crustal melting in the Everest region of the Nepalese Himalaya. Geology, 28, 403-406.

Stacey J. S. \& Kramers, J. D. 1975. Approximation of terrestrial lead isotope evolution by a two-stage model. Earth and Planetary Science Letters, 26, 207-221.

Waters, D. J. \& Lovegrove, D. P. 2002. Assessing the extent of disequilibrium and overstepping of prograde metamorphic reactions in metapelites from the Bushveld Complex aureole, South Africa. Journal of Metamorphic Geology, 20, 135-149.

Watts, D. R., Harris, N. B. W. \& The 2002 NASA GLENN SOARS Working Group. 2005. Mapping granite and gneiss in domes along the North Himalayan antiform with ASTER SWIR band ratios. GSA Bulletin, 117, 879-886.

Zhang, H., Harris, N., Parrish, R. et al. 2004. Causes and consequences of protracted melting of the mid-crust exposed in the North Himalayan antiform. Earth and Planetary Science Letters, 228, 195-212.

Received 16 March 2006; revision accepted 30 June 2007. 


\section{Author Query Form}

\section{Journal: $\quad$ JMG}

Article: $\quad 731$

Dear Author,

During the copy-editing of your paper, the following queries arose. Please respond to these by marking up your proofs with the necessary changes/additions. Please write your answers on the query sheet if there is insufficient space on the page proofs. Please write clearly and follow the conventions shown on the attached corrections sheet. If returning the proof by fax do not write too close to the paper's edge. Please remember that illegible mark-ups may delay publication.

Many thanks for your assistance.

\begin{tabular}{|c|c|c|}
\hline $\begin{array}{l}\text { Query } \\
\text { reference }\end{array}$ & Query & Remarks \\
\hline 1 & $\begin{array}{l}\text { Author: please provide the names of all authors (with initials) for this } \\
\text { personal communication. }\end{array}$ & \\
\hline 2 & Author: Table 4 has been changed to Figure 15 . Please check. & \\
\hline 3 & $\begin{array}{l}\text { Author: Watt \& Harley (1993) has not been included in the list, please } \\
\text { supply publication details. }\end{array}$ & \\
\hline 4 & $\begin{array}{l}\text { Author: Jamieson, Beaumont, Medvedev, Nguyen (2004) not cited. Please } \\
\text { cite reference in text or delete from the list. }\end{array}$ & \\
\hline 5 & Author: please provide chapter title. & \\
\hline 6 & Author: please provide the place of publication. & \\
\hline 7 & $\begin{array}{l}\text { Author: Pitra, Guiraud (1996) not cited. Please cite reference in text or } \\
\text { delete from the list. }\end{array}$ & \\
\hline 8 & Author: grain numbers 2 and 3 are missing. Please check. & \\
\hline 9 & $\begin{array}{l}\text { Au: Figures } 1,2,3,4,5,6,8,10,12,13,14 \text { have been supplied as Low } \\
\text { Resolution images. Please supply high resolution images. For guidelines on } \\
\text { electronic graphics, please see http://www.blackwellpublishing.com/bauthor/ } \\
\text { illustration.asp }\end{array}$ & \\
\hline
\end{tabular}




\section{Please correct and return this set}

Please use the proof correction marks shown below for all alterations and corrections. If you wish to return your proof by fax you should ensure that all amendments are written clearly in dark ink and are made well within the page margins.

\begin{tabular}{|c|c|c|}
\hline Instruction to printer & Textual mark & Marginal mark \\
\hline Leave unchanged & ... under matter to remain & ( ) \\
\hline $\begin{array}{l}\text { Insert in text the matter } \\
\text { indicated in the margin }\end{array}$ & $h$ & $\begin{array}{l}\text { New matter followed by } \\
h \text { or } h \otimes\end{array}$ \\
\hline Delete & $\begin{array}{l}\text { I through single character, rule or underline } \\
\text { or }\end{array}$ & $\sigma$ or $\sigma(x)$ \\
\hline $\begin{array}{l}\text { Substitute character or } \\
\text { substitute part of one or } \\
\text { more word(s) }\end{array}$ & I through letter or & $\begin{array}{l}\text { new character / or } \\
\text { new characters / }\end{array}$ \\
\hline Change to italics & — under matter to be changed & $\leftarrow$ \\
\hline Change to capitals & $\equiv$ under matter to be changed & $\equiv$ \\
\hline Change to small capitals & $=$ under matter to be changed & $=$ \\
\hline Change to bold type & $\sim$ under matter to be changed & $\sim$ \\
\hline Change to bold italic & $\bar{\sim}$ under matter to be changed & $\underline{s i n}$ \\
\hline Change to lower case & Encircle matter to be changed & $\Rightarrow$ \\
\hline Change italic to upright type & (As above) & \\
\hline Change bold to non-bold type & (As above) & \\
\hline Insert 'superior' character & $\begin{array}{l}/ \text { through character or } \\
K \text { where required }\end{array}$ & $\begin{array}{l}y^{\prime} \text { or } y \\
\text { under character } \\
\text { e.g. } y^{2} \text { or } y^{2}\end{array}$ \\
\hline Insert 'inferior' character & (As above) & $\begin{array}{l}\lambda \\
\text { over character } \\
\text { e.g. } \hat{\Sigma}\end{array}$ \\
\hline Insert full stop & (As above) & $\odot$ \\
\hline Insert comma & (As above) & , \\
\hline Insert single quotation marks & (As above) & $\begin{array}{l}\dot{y} \text { or } \dot{x} \text { and/or } \\
\dot{y} \text { or } \dot{y}\end{array}$ \\
\hline Insert double quotation marks & (As above) & $\begin{array}{l}\ddot{y} \text { or } \ddot{y} \text { and/or } \\
\ddot{y} \text { or } \ddot{y}\end{array}$ \\
\hline Insert hyphen & (As above) & 1 \\
\hline Start new paragraph & 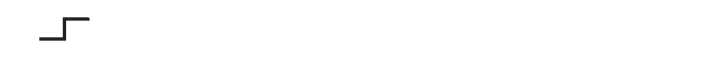 & 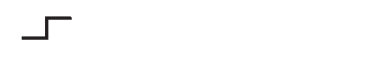 \\
\hline No new paragraph & $\infty$ & $\omega$ \\
\hline Transpose & $\sqcup$ & $\sqcup$ \\
\hline Close up & linking $\bigcirc$ characters & \\
\hline $\begin{array}{l}\text { Insert or substitute space } \\
\text { between characters or words }\end{array}$ & $\begin{array}{l}\text { I through character or } \\
\Lambda \text { where required }\end{array}$ & \\
\hline $\begin{array}{l}\text { Reduce space between } \\
\text { characters or words }\end{array}$ & $\begin{array}{l}\text { between characters or } \\
\text { words affected }\end{array}$ & $\uparrow$ \\
\hline
\end{tabular}

